\title{
Biomanufacturing process for the production of bacteriocins from Bacillaceae family
}

\author{
Ahmad Firdaus B. Lajis ${ }^{1,2^{*}}$ (D)
}

\begin{abstract}
Members of Bacillaceae family are of major interest in medical industry due to vast antimicrobial peptides they produce as therapeutic agents. For decades, synthetic and natural occurring antibiotics have been used to treat infectious diseases, but heavy dependence on these drugs has led to significant drawbacks which propel continuous development of new antibiotics generation. Recent findings have shown several bacteriocins of Bacillaceae as promising alternatives to the conventional drugs to combat the emergence of new drug-resistant pathogens. In this present review, Bacillaceae bacteriocins' classification such as lantibiotics and thiazole/oxazole-modified microcins as well as their biochemical characterization such as sensitivity to enzymes, temperature, $\mathrm{pH}$ and chemicals are described. This article enlightens on the medical application of several Bacillaceae bacteriocins emphasizing those that underwent and on-going preclinical trials. This review also discusses the development of Bacillaceae bacteriocins production, focusing strains selection and fermentation factors such as inocula size, medium (carbon, nitrogen, minerals sources), temperature, $\mathrm{pH}$, agitation and aeration rate, dissolved oxygen tension (DOT), fermentation time, inducers and mode of operation via various statistical methods for their optimization. It also highlights recent advance in the production of bioengineered and recombinant bacteriocins in bioreactors system which are rarely disclosed in literature.
\end{abstract}

Keywords: Antimicrobial peptide, Bacillus sp., Fermentation, Lantibiotic, Preclinical trial, Recombinant fusion

\section{Introduction}

Bacteriocins are proteinaceous antimicrobial substances, ribosomally synthesized by several members of phylum Firmicutes and Actinobacteria (Repka et al. 2017; Lawton et al. 2007; Arias et al. 2013; Somsap et al. 2016; Barbosa et al. 2015; Sandiford 2017; Shi et al. 2012). Halobacteria also produce bacteriocin-like antimicrobial substances known as archeocins (e.g. halocins) (Sandiford 2017). They can be structurally linear or globular and the arrangement of the amino acids sequence and formation determine their bacteriocidal activity, sensitivity

\footnotetext{
*Correspondence: ahmadlajis@hotmail.com

1 Department of Bioprocess Technology, Faculty of Biotechnology and Biomolecular Sciences, Universiti Putra Malaysia, 43400 UPM Serdang, Selangor, Malaysia

Full list of author information is available at the end of the article
}

towards enzymes, solubility and stability at different $\mathrm{pH}$ and temperature (Sandiford 2017; Herzner et al. 2011). Their spectra of bacteriocidal activity are varied; they can be broad (e.g. sensitive to several kinds of bacteria, antinobacteria, yeast and fungi) or narrow to only related genus and subspecies (van der Donk and Nair 2014). For many years, apart from thermal inactivation, bacteriocins are considered as another effective approach to eliminate and biologically control growth of prospective pathogenic microbes in foods. The application of bacteriocins in food biopreservation (e.g. vegetables-fruits, meat and dairy products) is well-accepted as an alternative and has been proven to be equally effective as chemical preservatives (McAuliffe et al. 2001).

Recently, there is a shifting trend in the application of bacteriocins in food spoilage bioprevention to medical 
application against infectious diseases. This is due to the emergence of various antibiotic-resistant pathogens as well as the side effects of the drugs (Bastos et al. 2017; van der Donk and Nair 2014; Cotter et al. 2012). Antibiotics with $\beta$-lactams ring and glycopeptides which inhibit bacterial cell wall synthesis are examples of antibiotic classes that are challenged with this problem (Bastos et al. 2017; Ratchaneewan and Pipatsatitpong 2014). Particularly, methicillin-resistant Staphylococcus aureus is specifically resistant to methicillin and can cause serious skin problems involving abnormal pigmentation, mastitis and swelling (Ratchaneewan and Pipatsatitpong 2014). Broad range antibiotics were also identified to cause number of complications related to collateral damage of the microbiota (e.g. in gastrointestinal tract) such as antibiotic associated diarrhoea and $C$. difficile infection (Rea et al. 2010; Ratchaneewan and Pipatsatitpong 2014; Cotter et al. 2012). Problem associated with microbial dysbacteriosis may also contribute to chronic diseases such as rheumatoid arthritis, diabetes, inflammatory bowel infection and obesity (Ratchaneewan and Pipatsatitpong 2014).

Most attention has been given to bacteriocins of lactic acid-producing bacterium (LAB) due to their GRAS (generally recognized as safe) status and probiotic characteristic, whereby their application in industry has been immensely reviewed (Sandiford 2017; McAuliffe et al. 2001). For instance, bacteriocins such as nisin and pediocin from Lactococcus lactis and Pediococcus acidilactici, respectively, are effective as biocontrol of Listeria monocytogenes in food (McAuliffe et al. 2001). However, they are not completely effective against several Gram-negative (G-ve) and Gram-positive (G+ve) pathogens such as Clostridium tyrobutyricum and Clostridium difficile (Sandiford 2017; van der Donk and Nair 2014). In addition, antibiotic-resistant pathogenic microbes such as methicillin-resistant Staphylococcus aureus, is resistant to many LAB bacteriocins (Bastos et al. 2017; Ratchaneewan and Pipatsatitpong 2014). In contrast, bacteriocins of Bacillaceae species display more powerful bacteriocidal and bacteriolytic activity; as compared to LAB bacteriocins such as enterocins in which the latter may only possess bacteriocidal effect (Sandiford 2017). In addition, Bacillaceae bacteriocins such as geobacillin-I showed greater stability than nisin at various conditions (Garg et al. 2012, 2014). Storage instability and continuous degradation at neutral $\mathrm{pH}$ are some drawbacks of nisin (Garg et al. 2014; Sharma et al. 2011). Thus, bacteriocins of Bacillaceae species could be a better option as compared to that of bacteriocins of $\mathrm{LAB}$ as well as conventional antibiotics where multidrug resistance has become more prominent nowadays (Islam et al. 2012; van der Donk and Nair 2014; Ratchaneewan and Pipatsatitpong 2014).
Bacteriocins of Bacillaceae species are effective in eliminating a specific number of clinically related pathogens such as methicillin-resistant Staphylococcus aureus, $P$. aeruginosa, vancomycin-resistant enterococci (VRE), Candida albicans, C. tyrobutyricum and C. difficile, which disclosed their great potential for medicinal purpose (Islam et al. 2012; Ratchaneewan and Pipatsatitpong 2014; Cotter et al. 2012; Garg et al. 2014). Preclinical study has been conducted whereby candidates such as mersacidin and penisin have shown promising effect against Staphylococcal, methicillin-resistant Staphylococcus aureus, Enterococcal (includes VRE) and C. difficile-associated disease (CDAD) (McAuliffe et al. 2001; Islam et al. 2012; Field et al. 2015; Baindara et al. 2015). Although many bacteriocins have been discovered and produced, they are still extensively studied especially in regards to their biomanufacturing process in order to fulfil commercial demands in forthcoming future. Little attention has been given to improve the production process either by mutation or bioengineered strains. This review describes the classifications and biochemical characterization of several known Bacillaceae bacteriocins so far as well as their recent progress in medicine. Biomanufacturing process of their production via fermentation techniques are elaborated in detail focusing on many internal and external factors such as strains, inocula size, medium composition, temperature, $\mathrm{pH}$, agitation and aeration rate, inducers, bioreactor design, mode of operation, fermentation time as well as optimization approaches using known statistical tools. Recent knowledge in bioengineering of bacteriocins is also described in this article.

\section{Classification of bacteriocins}

Post-translationally modified bacteriocins

Several bacteriocins are characterized at the levels of peptide structure, genetic determinants and biosynthesis mechanisms to allow proper bacteriocins classification (Kobayashi et al. 2016; Lohans and Vederas 2014; Lim et al. 2016; Teng et al. 2012; Huang et al. 2016). The bacteriocins of Bacillaceae species can be generally divided into two major classes, one with a post-translationally modified peptides and nonmodified peptides. Bacteriocins from post-translationally modified peptides groups (Class I) can be further categorized into several subgroups such as lantibiotics, thiazole/oxazolemodified microcins (TOMMs) and sactibiotics (Table 1) (van der Donk and Nair 2014; Murphy et al. 2011; Singh and Sareen 2014; McAuliffe et al. 2001). Lantibiotics are antibiotics with lanthionine, and its synthesis seems to be determined by their leader peptides sequences, which guide the pre-peptides to their particular modification machineries (Goto et al. 2010). In lantibiotics, 


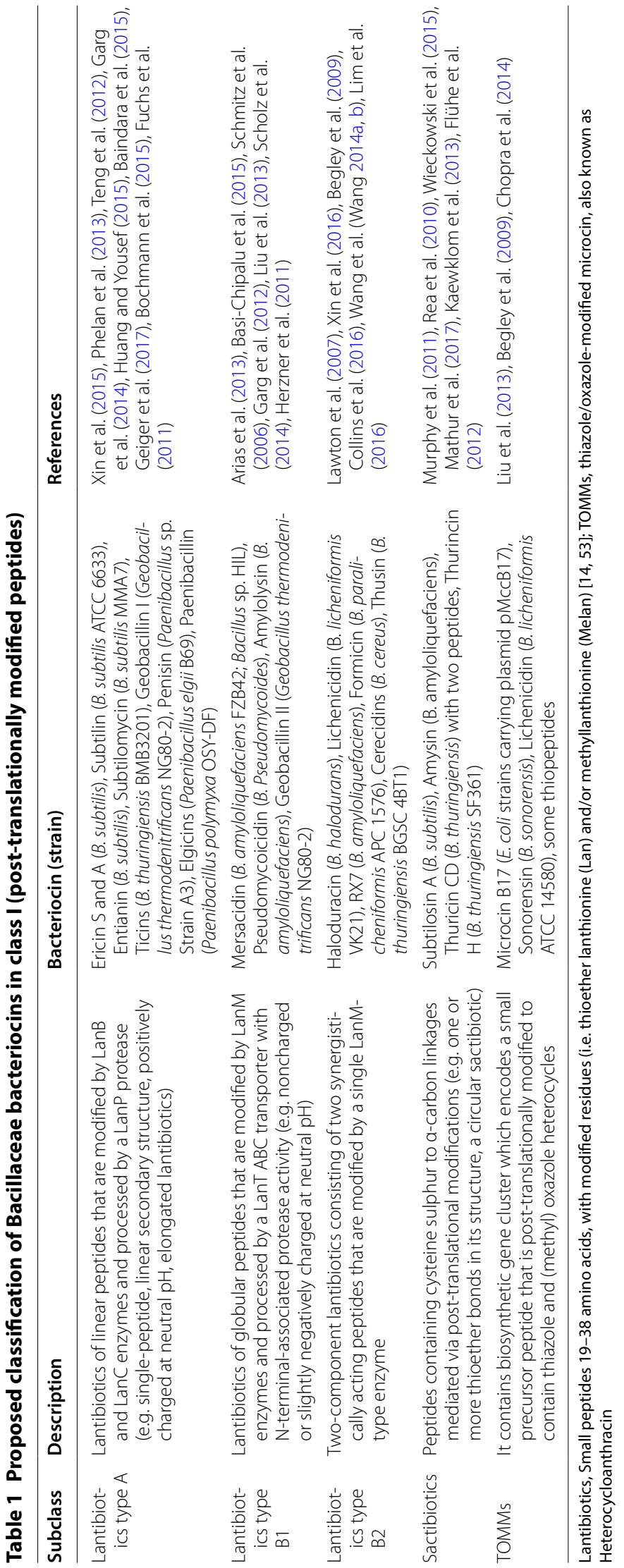


the modified precursor peptide is exported through LanT (an ATP-binding cassette $[\mathrm{ABC}]$ transporter), via the cytoplasmic membrane which later the leader peptide is cleaved by LanP extracellular protease to release the active lantibiotic which is one of the indicator for modified peptide classification (Singh and Sareen 2014; McAuliffe et al. 2001). In its biosynthesis, LanA is synthesized as a linear precursor peptide comprising leader peptide and core peptide at $\mathrm{N}$-terminal and C-terminal, respectively (van der Donk and Nair 2014; McAuliffe et al. 2001). Then, LanA underwent several processes of alteration where specific threonine or serine residues in the core peptide are dehydrated into 2,3-didehydrobutyrine or didehydroalanine. It later changed into methyl lanthionine (MeLan) or Lan residues with cysteine residues. Members of the Bacillaceae species are known to produce several types of lantibiotics as described below (Singh and Sareen 2014).

\section{Lantibiotics type A}

In lantibiotics type $\mathrm{A}$, dehydration and cyclization are catalysed by dehydratase LanB and cyclase LanC, respectively (van der Donk and Nair 2014; McAuliffe et al. 2001). The examples of type A are subtilin, entianin, ericin S and ericin A (Geiger et al. 2017; Bochmann et al. 2015; Fuchs et al. 2011). B. subtilis (e.g. strain ATCC 6633, 168 ) produced subtilin, a type A lantibiotic, with lanthionine ring structure molecularly similar to nisin of LAB but without carbohydrate and lipid residues or disulfide bridges which are identification for class II bacteriocinnonmodified peptides (e.g. Pediocin-like peptide) (Geiger et al. 2017; Yu et al. 2013). Even though subtilin and ericin are produced by $B$. subtilis, their resistance to proteolytic enzymes are different wherein subtilin was tolerant to proteinase $\mathrm{K}$, while ericin $\mathrm{S}$ and ericin A were tolerant to trypsin and pepsin (Geiger et al. 2017). In comparison to subtilin, entianin are also lantibiotics subclass I, produced by B. subtilis subsp. spizizenii DSM 15029T, but with unusual ring structures (Geiger et al. 2017; Bochmann et al. 2015; Fuchs et al. 2011). Subtilin and its likes exert strong bacteriocidal activity against various infectious pathogens including methicillin-resistant Staphylococcus aureus and vancomycin-resistant enterococci with comparable competence to that of nisin. They may also partially undergo a further post-translational modification, where the tryptophan residue at the $\mathrm{N}$-terminal is succinylated, hence drastically reduced its bacteriocidal activity (Bochmann et al. 2015). The subtilomycin, a B. subtilis MMA7 derived lantibiotic was an elongated peptides with a hinge region, vitally important for pores formation (McAuliffe et al. 2001; Phelan et al. 2013). On the other hand, Geobacillin I structure composed of thioether bridges, dehydroalanine and dehydrobutyrine at 7:1:1 ratio, respectively (Jarrett 2014; Garg et al. 2014). Even though C-terminal structures of Geobacillin-I are different from nisin, both $\mathrm{N}$-terminal rings of Geobacillin-l and nisin are almost similar (Garg et al. 2014).

\section{Lantibiotics type $B$}

In lantibiotics type B in contrast, Lan or MeLan rings are incorporated by a bifunctional modification enzyme LanM (van der Donk and Nair 2014; McAuliffe et al. 2001). The lantibiotics type $B$ are further divided into subclasses, e.g. type B1 and B2. Lantibiotic type B2 differs from B1, by containing two components peptide which act synergistically. Examples of lantibiotics subclass B1 are mersacidin, Paenibacillin, Actagardine, Michiganin A, Amylolysin, and Pseudomycoicidin (Arias et al. 2013; Basi-Chipalu et al. 2015; Field et al. 2015; Schmitz et al. 2006; Shi et al. 2012). Mersacidin binds to lipid II and inhibits the synthesis of peptidoglycan cell wall in susceptible G+ve bacteria (which may differ from some LAB bacteriocins such as Pep5), which form pores in cytoplasmic membrane that lead to cell leakage and cell death (Schmitz et al. 2006). Moreover, mersacidin-lipid II binding motif, is conserved in some reported lantibiotics. It was noted that core peptide at N-terminal part which harbours an amino acid (CTxTxDC) sequence resembling the conserved mersacidin-like lipid II (CTxT/ SxE/DC) binding motif can be found in other class II lantibiotics (Schmitz et al. 2006). Pseudomycoicidin of B. pseudomycoides DSM 12442 is a lantibiotic that carries thioether bridges and disulfide bridge at 4 to 1 ratio. Pseudomycoicidin, a one-component peptide was found to be resistant to trypsin, suggesting that the trypsin cleavage site located in the conserved lipid-II binding motif is shielded by the presence of thioether ring structure (Basi-Chipalu et al. 2015; Jarrett 2014). The leader sequence at the $\mathrm{N}$ terminal of pseudomycoicidin shows very high similarity to mersacidin prepeptide MrsA; thus, it directs the peptides to LanM for dehydration and cyclization (Basi-Chipalu et al. 2015).

Lantibiotic type B2 consisted of two-component lanthipeptides such as Haloduracin, Lichenicidin VK21, RX7 bacteriocin, geobacillin II and Formicin (Lawton et al. 2007; Begley et al. 2009; Collins et al. 2016; Dischinger et al. 2009; Lim et al. 2016). A disulfide bridge is also present within the active haloduracin, post-translational modification lantibiotic peptides (Lawton et al. 2007; Basi-Chipalu et al. 2015). In the alpha peptide haloduracin, the two $\mathrm{N}$-terminal Cys residues form the disulfide bridge. Interestingly, the bacteriocin RX7 with initial 15 amino acids sequence showed high homology with the dipeptide lantibiotic haloduracin (Lawton et al. 2007; Lim et al. 2016). Other example in the same class such as cerecidin showed a similarity with two-component 
cytolysins, a lantibiotic of Enterococci at ring topologies in these counter constituents (Wang et al. 2014b).

\section{Lantibiotics type $C$ and $D$}

The synthesis of lantibiotics type $\mathrm{C}$ is catalysed by tridomain proteins LanKC (van der Donk and Nair 2014; McAuliffe et al. 2001). This type of lantibiotics is usually referred to lantipeptides due to their functions in morphogenetic development (e.g. aerial mycelium formation) and displays very limited antimicrobial activities. Lantibiotics Type D is a proposed class of lantibiotic where its synthesis is catalysed by LanL (McAuliffe et al. 2001). This class is almost similar to Type $C$, but differs in cyclase domain of the synthetase. So far none type $\mathrm{C}$ and $\mathrm{D}$ have been reported from Bacillaceae species while several known from actinomycete and other species.

\section{Heterocycloanthracin}

The TOMMs group are heterocycloanthracin, a group of putative peptides consist of oxazole and/or thiazole heterocycles (Liu et al. 2013). They contain biosynthetic gene cluster which encodes a small size precursor peptide that is post-translationally modified to contain thiazole and (methyl) oxazole heterocycles structure. These rings are derived from cystine and serine/threonine residues via the action of cyclodehydratase, a dehydrogenase, and a docking protein, a trimeric synthetase complex (Begley et al. 2009). The bacteriocins of such are classified as TOMMs due to their conserved genetics and chemical structures in many species. In TOMM biosynthesis, the trimeric synthetase complexes recognize and bind to precursor peptide via the specific motifs of its $\mathrm{N}$-terminal leader sequence (Repka et al. 2017; van Der Donk and Nair 2014). This allows heterocycles synthesis on the $\mathrm{C}$-terminal core peptide via cyclodehydratase enzymatic processes, which converts cystine into thiazolines and serine/threonine residues into (methyl)oxazolines (van Der Donk and Nair 2014; Repka et al. 2017). This process is followed by an oxidation process by dehydrogenase which converts the azoline rings to thiazoles and (methyl) oxazoles rings. The TOMMs' biosynthesis is completed by the integration of auxiliary modifications (e.g. dehydrations, methylations, macrocyclization) and leader peptide proteolysis. Then, the complete matured form of TOMMs can be actively exported from the cell facilitated by an $A B C$ transport system. This class of bacteriocins includes microcin B17, sonorensin, lichenicidin ATCC14580 and some thiopeptides (Liu et al. 2013; Begley et al. 2009). Sonorensin had a considerably similar structure to the recognized thiazolecontaining heterocyclic lichenicidin of B. licheniformis, and its N-terminal sequence is homologous to the leader sequence of pro-toxins from many Bacillus strains (Begley et al. 2009; Chopra et al. 2014).

\section{Sactibiotics}

Subtilosin A (35 amino acids), a macrocyclic bacteriocin was used as an example, for extensively post-translationally modified bacteriocin by tri-covalent thioether linkages, with cystein- $\alpha$ carbon linkage, as well as the linkage between the $\mathrm{N}$ - and $\mathrm{C}$-terminal and cleaves at the N-terminal extension (Murphy et al. 2011; Jarrett 2014; Flühe et al. 2012). This is supported by similar sactibiotics structure such as thuridicn $\mathrm{CD}$, thurincin $\mathrm{H}$, amysin and hyicin 4244 (Murphy et al. 2011; Wieckowski et al. 2015; Kaewklom et al. 2013). Neither of them shows similarity to class II Pediocin nor contain lipid-fat, carbohydrate-sugar residues or even disulfide bridges. Thurincin $\mathrm{H}$ is a 31-residue lantibiotic with four thioether bridges between $\alpha$-carbons of a serine, two threonines, an asparagine residue and the four cysteines. Thurincin $\mathrm{H}$ slightly differs from others where it lacks the two-glycine (GlyGly) motif attribute of the leader sequence recognized by $A B C$ transport system (Wieckowski et al. 2015). The classification of Sactibiotic group of bacteriocin is supported by the appearance of bacteriocin hyicin 4244 from non Bacillus species such as Staphylococcus which exhibited genetically similar gene cluster (hyiSABCDEFG) to that of subtilosin A from B. Subtilis with three thioether bonds in its structure (Murphy et al. 2011; Flühe et al. 2012). Conversely, bacteriocin KKU213 showed gene sbo/alb cluster similarity to that of subtilosin A gene of $B$. subtilis (Flühe et al. 2012; Khochamit et al. 2015). Recent study also showed that specific radical S-adenosylmethionine enzymes (e.g. AlbA, TrnC and TrnD) catalyses the construction of thioether bond in subtilosin $\mathrm{A}$ and thurincin $\mathrm{H}$ and also suggested in thuricin $\mathrm{CD}$ (Wieckowski et al. 2015; Jarrett 2014; Flühe et al. 2012). The formation of thioether bonds in lantibiotic differs from sactibiotic, whereby the earlier mentioned bacteriocin had cysteine cross-linked to dehydroserine/threonine via Michael-type addition, but the latter had cysteine attached to $\alpha$-carbon of any amino acid via action of a radical S-adenosylmethionine enzyme (Jarrett 2014).

\section{Nonmodified bacteriocins}

Class II (nonmodified peptides) can be divided into several subclasses (Table 2). Members of the Bacillaceae species also synthesize nonlantibiotics bacteriocins such as class II type A (cystibiotic), which have many similarities to the pediocin-like bacteriocins of the P. acidilactici. For example, Coagulin, produced by B. coagulans I, is a pediocin-like bacteriocin, homologous to pediocin $\mathrm{AcH} / \mathrm{Pa} 1$ with high antilisterial activity (Hyronimus et al. 1998). Other bacteriocins such as Entomocin 110, SRCAM 37, SRCAM 602 and SRCAM 1580 from B. thuringiensis, $P$. polymyxa NRRL B-30507, B-30509 and B-30644, respectively, were proposed to fall into this category (Cherif 
Table 2 Proposed classification of Bacillaceae bacteriocins in class II (post-translationally unmodified peptides)

\begin{tabular}{|c|c|c|c|}
\hline Subclass & Description & Bacteriocin (strain) & References \\
\hline Type A (cystibiotic) & $\begin{array}{l}\text { Pediocin-like bacteriocins contains } \\
\text { medium-length bacteriocins (37-48 } \\
\text { residues) with strong antilisterial } \\
\text { activity. The group contain a con- } \\
\text { served N-terminal sequence-the } \\
\text { YGNGV "pediocin box"-and one or } \\
\text { two intra-chain disulfide bonds }\end{array}$ & $\begin{array}{l}\text { Coagulin (B. coagulans) } \\
\text { Entomocin } 110 \text { (B. thuringiensis subsp. } \\
\text { entomocidus) } \\
\text { SRCAM } 37 \text { (P. polymyxa NRRL B-30507) } \\
\text { SRCAM } 602 \text { (P. polymyxa NRRL } \\
\text { B-30509) } \\
\text { SRCAM 1580 (B. circulans NRRL } \\
\text { B-30644 } \\
\text { Thermocins (Geobacillus stearother- } \\
\text { mophilus) }\end{array}$ & $\begin{array}{l}\text { Cherif et al. (2008), Pokusaeva et al. } \\
\text { (2009), Hyronimus et al. (1998), } \\
\text { Svetoch et al. (2005) }\end{array}$ \\
\hline Type B (thuricin-like peptide) & $\begin{array}{l}\text { Bacteriocins shared similar N-terminal } \\
\text { sequence with the anti-Listeria } \\
\text { bacteriocin thuricin S) }\end{array}$ & $\begin{array}{l}\text { Thuricin S (B. thuringiensis HD198) } \\
\text { Thuricin } 17 \text { (B. thuringiensis) } \\
\text { Bacthuricin F4 (B. thuringiensis) } \\
\text { Cerein MRX1 (B. cereus) } \\
\text { Thuricin } 7 \text { (B. thuringiensis BMG1.7) } \\
\text { EntomocinHD9 (B. thuringiensis subsp. } \\
\text { entomocidus) } \\
\text { Tochicin (B. thuringiensis subsp. tochi- } \\
\text { giensis HD868) } \\
\text { Thuricin HD2 (B. thuringiensis subsp. } \\
\text { thuringiensis) }\end{array}$ & $\begin{array}{l}\text { Cherif et al. (2008), Salazar-Marroquín } \\
\text { et al. (2016) }\end{array}$ \\
\hline Type C & $\begin{array}{l}\text { Two-peptide bacteriocins whose } \\
\text { antimicrobial activity relies on the } \\
\text { complementary action of the two } \\
\text { different peptides }\end{array}$ & Thuricin 439 (B. thuringiensis B439) & Huang et al. (2016) \\
\hline Type D & $\begin{array}{l}\text { One-peptide noncyclic bacteriocins } \\
\text { that show no sequence similarity to } \\
\text { other bacteriocins. It also includes } \\
\text { a leaderless bacteriocin subgroup } \\
\text { whose members are different from } \\
\text { most bacteriocins in that they do } \\
\text { not involve an N-terminal leader } \\
\text { sequence for exporting nonpedi- } \\
\text { ocin linear one-peptide }\end{array}$ & $\begin{array}{l}\text { Cerein 7A (B. cereus) } \\
\text { Cerein 7B (B. cereus) } \\
\text { Lichenin (B. licheniformis) } \\
\text { BLIS (Virgibacillus salexigens) }\end{array}$ & $\begin{array}{l}\text { Pattnaik et al. (2001), Ovchinnikov et al. } \\
\text { (2016), Luca et al. (2002) }\end{array}$ \\
\hline
\end{tabular}

Class II is nonlantibiotics bacteriocins contain peptides without modified residues or with minor modifications (e.g. disulfide bridge or circularization)

et al. 2008; Kaewklom et al. 2013). The 3D molecular conformation of pediocin-like bacteriocins was stabilized by tryptophan residues. Moreover, relatively high proportion of Trp residues at the $\mathrm{C}$ and $\mathrm{N}$ terminal part of the core peptide may contribute to the insertion of the peptide into the targeted cell membrane. In addition, many antilisterial-like bacteriocins contained YGNGVXC motif at N-terminal (Kaewklom et al. 2013). Many other pediocin-like bacteriocins also share similarity of a $\beta$-sheet-rich amino acid sequence.

Class II type B was proposed to include thuricin-like peptide, using several bacteriocins of $B$. thuringiensis as prototype (Salazar-Marroquín et al. 2016). Although some $B$. thuringiensis are excluded, a number of similar characterized bacteriocins are currently categorized under thuricin-like peptides. These include thricin S, thuricin HD2, thuricin 7, cerein MRX1, entomocin 9, thuricin 17, tochicin HD868, tolworthcin 524 and bacthuricin F4 (Cherif et al. 2008; Pacheco-Cano et al. 2014). In this group, thuricin 17 , tolworthcin 524 and thuricinlike peptide do not possess the glycine-glycine motif characteristic of the secretion leader peptides (8-27 amino acids) recognized by $\mathrm{ABC}$ transportation system (Pacheco-Cano et al. 2014; Dominguez et al. 2007). Tolworthcin 524 and other thuricin-like peptide share the preserved motif DWTXWSXL in amino acid sequences (Pacheco-Cano et al. 2014). In particular, the N-terminal part of the pre-bacteriocin form of thuricin 17 is similar to those of the tolworthcin 524 partial sequences, METPVVQPR (Pacheco-Cano et al. 2014). Separately, class II Type $C$ bacteriocins contained two molecules work synergistically such as thuricin B439 (Ayed et al. 2015). In another subclass, Type D such as Cerein 7 and $8 \mathrm{~A}$ of $B$. cereus are linear peptides that showed significant antimicrobial activity on L. monocytogenes and B. cereus (Dominguez et al. 2007).

\section{Other type of bacteriocins}

Classification of bacteriocins class III, IV and V is summarized in Table 3. Class III is bacteriocins with large molecules size $(>30 \mathrm{kDa})$ and heat labile such as Megacin A (66-68 kDa), NCPP32355 (45-76 kDa) and SW1-1 
(38 kDa) (Kim et al. 2014; Antal et al. 2008). For instance, bacteriocin SW1-1 showed bacteriocidal activity against marine pathogens. Particularly, it significantly inhibited the growth of Edwardsiella tarda via cell wall degradation (Kim et al. 2014). It was intolerant to the proteolytic degradation of pepsin, trypsin, chymotrypsin, and proteases (e.g. I and XIV) while relatively stable in the $\mathrm{pH}$ buffer solution range from 2.0 to 11.0 as well as in various organic solvents (Kim et al. 2014). Class IV is a group of complex bacteriocins carrying lipid-fat or carbohydratesugar moieties needed for their activity. The structure and function of this class was rarely studied and little is known about bacteriocin of this class from Bacillaceae species although bacteriocin-like inhibitory substance (BLIS) of Bacillus sp. H4 showed possible classification into this group (Compaoré et al. 2013).

Class $\mathrm{V}$ bacteriocins are emerging family of circular bacteriocins, peptides with a post-translational nonmodified head-to-tail-ligated cyclic peptides of their backbone. The main characteristic of these bacteriocins are their cyclization by formation of a peptide bond between the $\mathrm{N}-\mathrm{C}$ termini of a processed prepeptide via enzymatic reactions. The majority of them most likely adopt a common 3-D molecular structure consisting of one or more $\alpha$-helices encircling a hydrophobic core (Gabrielsen et al. 2014; Martin-Visscher et al. 2011). They were found to cause nonselective pores formation in the cell membranes of the targeted cells. They are also renowned by their thermostability and high isolelectric point. Amylocyclicin is one of the examples that belongs to this class (Liu et al. 2013; Martin-Visscher et al. 2011; Gabrielsen et al. 2014). The matured amylocyclicin displayed only small sequence match (23-34\%) to nonBacillaceae bacteriocins such as butyrivibriocin AR10, carnocyclin A and circularin A (Liu et al. 2013). So far, other unclassified bacteriocin such as laterosporulin $(5.6 \mathrm{kDa}$ amino acid sequence), of Brevibacillus sp. has also been reported. It contained dissimilar putative gene from other reported bacteriocins (Singh et al. 2012). Continuous N-terminal sequence analysis in laterosporulin showed the absence of modified amino acids like dehydrated serine or threonine which are formed as a result of post-translational modifications (Singh et al. 2012).

\section{Characterization of bacteriocins \\ Enzymes sensitivity}

There are a number of bacteriocin-like inhibitory substance (BLIS) have been reported, but their primary structure have not been fully elucidated. Bacteriocins and BLIS were submitted to a battery of biochemical characterization assays. Table 4 shows their susceptibility to enzymatic degradation by protease, lipase, amylase and other enzymes. Although being proteinaceous, they were not completely susceptible to all proteolytic enzymes, essentially depending on type and concentration. Nevertheless, many reported bacteriocins were sensitive to proteinase $\mathrm{K}$. The susceptibility of the bacteriocins to certain enzymes depends mainly on peptide formation and its amino acid sequence. For instance, resistance of BLIS $\mathrm{H} 4$ to papain and proteinase $\mathrm{K}$, was probably attributed to its cyclic peptide formation containing unusual amino acids sequence (Compaoré et al. 2013). Interestingly, their degree of degradation towards different proteolytic enzymes also differs according to their amino acid sequences. Particularly, subtilosin activity was completely lost in the presence of pepsin and proteinase $\mathrm{K}$, but some of its activity was still retained in the solution containing trypsin and chymotrypsin (Flühe et al. 2012). BLIS An6 was sensitive to proteinase $K$ but resistant to the proteolytic action of alcalase, trypsin, chymotrypsin and pepsin (Ayed et al. 2015). Similarly, entomocin 110 had $100 \%$ reduced activity after treatment with proteinase

Table 3 Proposed classification of Bacillaceae bacteriocins in class III, IV and V

\begin{tabular}{|c|c|c|c|}
\hline Class & Description & Bacteriocin (strain) & References \\
\hline Class III & $\begin{array}{l}\text { Large protein, molecular weights of more than } \\
30 \mathrm{kDa} \text { and sensitive to heat }\end{array}$ & $\begin{array}{l}\text { Megacin A-216 (B. megaterium 216) } \\
\text { Megacin A-1921 (B. megaterium 1921) } \\
\text { SW1-1 (Bacillus sp. SW1-1) }\end{array}$ & Kim et al. (2014), Antal et al. (2008) \\
\hline Class IV & $\begin{array}{l}\text { Complex bacteriocins composed of lipid/carbohy- } \\
\text { drates moiety. Mostly synthesized by LAB }\end{array}$ & Bacteriocin H4 (Bacillus sp.) & Compaoré et al. (2013) \\
\hline Class V & $\begin{array}{l}\text { Peptides consisting of ribosomally synthesized } \\
\text { nonmodified head-to-tail-ligated cyclic peptides } \\
\text { of their backbone. This process of leader peptide } \\
\text { removal, circularization, and secretion putatively } \\
\text { involves dedicated enzymatic reactions } \\
\text { Cyclization by formation of a peptide bond between } \\
\text { the } \mathrm{N} \text { and C termini of a processed prepeptide } \\
\text { Most circular bacteriocins probably adopt a common } \\
\text { 3D structure consisting of several a-helices encom- } \\
\text { passing a hydrophobic core }\end{array}$ & Amylocyclicin (B. amyloliquefaciens FZB42) & $\begin{array}{l}\text { Liu et al. (2013), Scholz et al. (2014), } \\
\text { Gabrielsen et al. (2014), Martin-Visscher } \\
\text { et al. (2011) }\end{array}$ \\
\hline
\end{tabular}




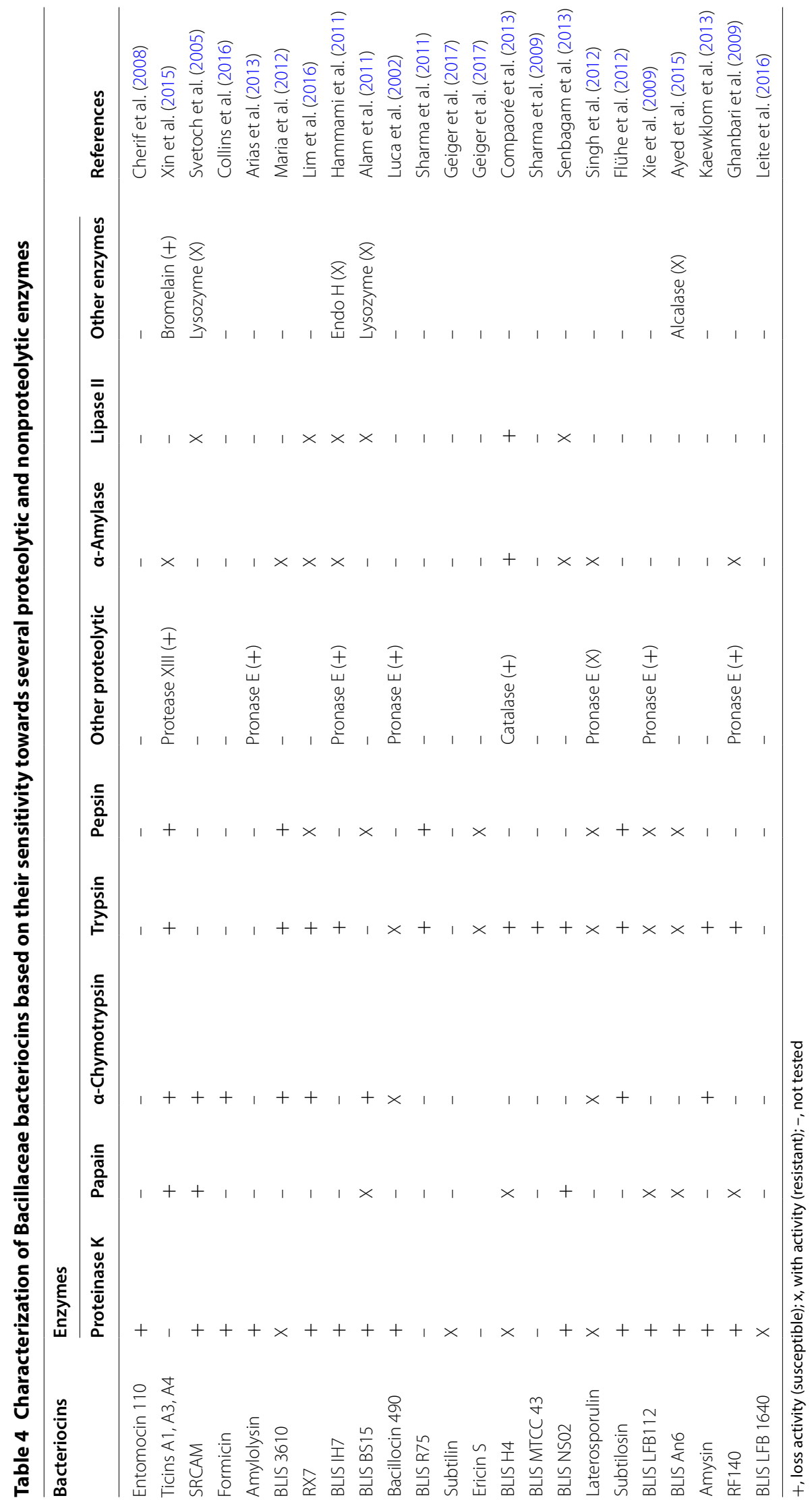


$\mathrm{K}$ at concentration of only $1 \mathrm{mg} / \mathrm{mL}$ (Cherif et al. 2008). The amysin was susceptible to all proteases only at high concentration, suggesting the proteinaceous character but with unique amino acids sequence (Kaewklom et al. 2013). Therefore, accessing their susceptibility at various enzyme concentrations is necessary to provide sufficient information about bacteriocins studied. Other similar cyclic antimicrobial peptides produced by Bacillaceae species containing unusual amino acids such as laterosporulin were also more resistant to proteases (Baindara et al. 2016). Other BLIS such as BLIS KKU213 was still active even after being treated with sequence-specific endoproteinases proteolytic enzymes, which suggests its resistance to digestion might be due to the inaccessibility of the specific recognition sites such as thermolysin (X-A), trypsin (Lys-X) and $\alpha$-chymotrypsin (FYW-X) (Khochamit et al. 2015). On the other hand, BLIS NS02 which was resistant to hydrolases such as amylase, diastase and lipase may be associated to the absence of carbohydrates and lipid moieties (Senbagam et al. 2013). In contrast, BLIS NCIMB 3610 was sensitive to lipase due to the presence of lipid moieties (Maria et al. 2012).

These findings are very useful in selection of bacteriocins for medicinal purpose and to choose the best route of drug delivery either via oral, intravenous or topical application. So far, many reported BLIS and bacteriocins such as from strains $B$. cereus NS02, B. licheniformis MKU3, B. subtilis $\mathrm{H} 4$ and $B$. mycoides are sensitive to trypsin (Kayalvizhi and Gunasekaran 2010). As such, these bacteriocins may not be delivered to targeted area orally. In contrast, BLIS LFB-FIOCRUZ 1640 and LFB112 were resistant to trypsin. Bacteriocins resistance towards enzymes in the digestive system such as pepsin, trypsin, amylase and peptidases, has made them as outstanding candidates to fight infectious intestinal pathogens (Leite et al. 2016; Xie et al. 2009). In addition, bacteriocin resistance towards proteolytic enzyme produced by pathogens is also an advantage. For instance, proteases such as PrtPI and PrtPIII which are present at the cell wall of $L$. lactis are able to digest bacteriocins such as LcnB, but are unable to degrade circularin A (Gabrielsen et al. 2014; Martin-Visscher et al. 2011). Some other bacteriocins such as cerein 8A and BLIS NS02 which was not affected by nonproteolytic enzymes such as diastase and lipase may be used to treat some other infection on other part of the body (Senbagam et al. 2013; Dominguez et al. 2007).

\section{pH stability}

Bacteriocin and BLIS stability towards acidic and alkaline milieu is summarized in Table 5 . It has been reported that BLIS NCIMB 3610 has very narrow pH stability, ranging from 6.0 to 8.5 (Maria et al. 2012). Comparatively, BLIS MKU3, KKU213 and An6 expressed slightly wider $\mathrm{pH}$ stability, ranging from 4.0 to 10.0 (Ayed et al. 2015; Leite et al. 2016; Khochamit et al. 2015). Bacteriocins which have $\mathrm{pH}$ stability to acidic and alkaline environment significantly has better advantage for treatment of gastrointestinal infection where drugs are intended to be given orally. Interestingly, bacteriocin such as cerein $8 \mathrm{~A}$ which is stable at a broad range of $\mathrm{pH}$ has been reported (Dominguez et al. 2007). Similarly, BLIS LFB-FIOCRUZ 1640, LFB112, R75 and B. mycoides was stable within a wide range of $\mathrm{pH}$, from 3.0 to 11.0 (Leite et al. 2016; Xie et al. 2009; Sharma et al. 2011). Moreover, amysin, entomocin 110 and BLIS BS15 from B. thuringiensis were stable in range $\mathrm{pH}$ of 3-9 (Alam et al. 2011; Kaewklom et al. 2013). The BLIS NS02 was very stable at wide $\mathrm{pH}$ range, from 4 to 9 and its conformation was not significantly affected even at $\mathrm{pH} 3$ and 10 (Senbagam et al. 2013). Attractively, thusin and some BLIS from $B$. subtilis expressed tolerance at very low $\mathrm{pH}$ of 2.0 (Xin et al. 2015; Kawulka et al. 2004). Although many reported bacteriocins were stable at broad $\mathrm{pH}$ but their activity over extended period of time were not known. There is a concern that under working environment and over prolonged time period would not give satisfactory antimicrobial effect in vivo. Thus, it is worthy to study on the relationship between its $\mathrm{pH}$ stability against time. In fact, $\mathrm{pH}$ plays a crucial role in the mechanism of inhibition. Bacteriocins target cell membrane to cause rapid cell death via a concentration-dependent pattern. For most cationic bacteriocin, cell lysis is stimulated by the association of negatively charged molecules present on the bacterial cell surface, such as lipopolysaccharide (LPS), lipoteichoic and teichoic acids. It has been suggested that the anionic and amphiphilic characteristics are necessary for their antimicrobial activity. On the other hand, the effect of $\mathrm{pH}$ on bacteriocins' isoelectric point (IEP) and charge value from $\mathrm{pH} 0$ to 14 is important for purification process. The use of IEP during downstream processing is very significant to increase purification factor and bacteriocins purity. Thus, identification of their stability towards different $\mathrm{pH}$ has its importance in bacteriocins selection for certain treatment and also has its significant attribution to purification process.

\section{Thermostability}

Bacteriocin or BLIS are mostly heat resistant, but their optimal temperature with highest antimicrobial activity varies depending on species. In common, cerein $8 \mathrm{~A}$, BLIS An6, LFB112, BS15, KKU213 and NCIMB 3610 were relatively heat resistant at temperature, ranging from 25 to $100{ }^{\circ} \mathrm{C}$. Thermostability at $37^{\circ} \mathrm{C}$ significantly allows their application as medicinal drug for animal and human. Moreover, their stability at fluctuated temperature will ensure its stability during storage (Xie et al. 
Table 5 Characterization of Bacillaceae bacteriocins based on their molecular mass and stability towards pH, heat as well as their other physio-chemical property

\begin{tabular}{|c|c|c|c|c|c|c|}
\hline Microorganism & Bacteriocin or BLIS & MW (kDa) & $\mathrm{pH}^{\mathrm{a}}$ & $\mathrm{Te}\left({ }^{\circ} \mathrm{C}\right) / \mathrm{Ti}(\min )^{\mathrm{a}}$ & $\begin{array}{l}\text { Physio-chemical } \\
\text { property }\end{array}$ & References \\
\hline B. licheniformis & Bacillocin 490 & 2 & $4.5-9$ & $100 / 60$ & - & Luca et al. (2002) \\
\hline B. licheniformis MKU3 & BLIS & 8 & $3-11$ & $100 / 10$ & - & $\begin{array}{l}\text { Kayalvizhi and Gunasekaran } \\
\text { (2010) }\end{array}$ \\
\hline $\begin{array}{l}\text { B. paralicheniformis APC } \\
1576\end{array}$ & Formicin & 3.3-3.4 & - & $100 / 30$ & - & Collins et al. (2016) \\
\hline B. mycoides & BLIS & - & $4-11$ & $100 / 10,90 / 20$ & $\begin{array}{l}\text { Solubilized in SDS }(0.6 \% \\
\text { wlv) }\end{array}$ & Basi-Chipalu et al. (2015) \\
\hline B.pseudomycoides & Pseudomycoicidin & 2.7 & $2-7$ & $100 / 60$ & - & Basi-Chipalu et al. (2015) \\
\hline $\begin{array}{l}\text { B. thuringiensis subsp. } \\
\text { Entomocidus }\end{array}$ & Entomocin HD1 10 & 4.8 & - & $-/-$ & Hydrophobic & Cherif et al. (2008) \\
\hline B. thuringiensis $\mathrm{BMG}$ & Thuricin 7 & 11.6 & - & $98 / 30$ & - & Pacheco-Cano et al. (2014) \\
\hline B. thuringiensis & Ticins A1, A3 and A4 & 4 & - & $-/-$ & - & Xin et al. (2015) \\
\hline B. thuringiensis & $\begin{array}{l}\text { Thuricin } 17 \text {, tolworthcin } \\
524\end{array}$ & $\sim 6$ & - & $-1-$ & IEP: 8 & Pacheco-Cano et al. (2014) \\
\hline B. thuringiensis & Thurincin $\mathrm{H}$ & 3.2 & - & $-1-$ & IEP: 3.7 & Wieckowski et al. (2015) \\
\hline B. amyloliquefaciens & Amylolysin, amylocyclicin & 3.3 & $2-9$ & $100 / 60$ & - & $\begin{array}{l}\text { Arias et al. (2013), Halimi } \\
\text { et al. (2010) }\end{array}$ \\
\hline B. amyloliquefaciens An6 & BLIS & 11 & $4-10$ & $-/-$ & - & Cavera et al. (2015) \\
\hline B. amyloliquefaciens RX7 & Haloduracin-like peptide & 5 & $1-10$ & $80 / 30$ & Hydrophobic & $\begin{array}{l}\text { Lawton et al. (2007), Lim } \\
\text { et al. (2016) }\end{array}$ \\
\hline $\begin{array}{l}\text { B. amyloliquefaciens SP- } \\
\text { 1-13LM }\end{array}$ & Amysin & 5.2 & $3-9$ & $100 / 60$ & - & Kaewklom et al. (2013) \\
\hline B. subtilis BS15 & BLIS & $3-5$ & $3-9$ & $80 / 30$ & Hydrophobic & Alam et al. (2011) \\
\hline B. subtilis IH7 & BLIS & 14 & $6-9$ & $121 / 15$ & - & Hammami et al. (2011) \\
\hline B. subtilis subsp. subtilis $\mathrm{H} 4$ & BLIS & 3.3 & $3-10$ & $-1-$ & Contains disulfide bridges & Compaoré et al. (2013) \\
\hline B. subtilis LFB112 & BLIS & 6.3 & - & $-/-$ & - & Xie et al. (2009) \\
\hline B. subtilis R75 & BLIS & 12 & $5-9$ & $90 / 10$ & - & Sharma et al. (2011) \\
\hline B. subtilis NCIMB 3610 & BLIS & 16 & $6-8.5$ & $100 / 60$ & - & Maria et al. (2012) \\
\hline B. cereus NSO2 & BLIS & $3.5-6$ & $3-10$ & $100 /-$ & Hydrophobic & Phelan et al. (2013) \\
\hline B. cereus & Cerein $8 \mathrm{~A}$ & 9 & - & $80 / 30$ & - & Dominguez et al. (2007) \\
\hline B. cereus & Cerein 7 & $2.9-3.94$ & - & $-/-$ & $\begin{array}{l}\text { Stimulated by Triton X } \\
100\end{array}$ & Dominguez et al. (2007) \\
\hline B. cereus SS28 & BLIS & - & $2-11$ & $121 / 15$ & - & Yusra et al. (2014) \\
\hline B. cereus LFB 1640 & BLIS & 24.8 & - & $80 / 30$ & - & Leite et al. (2016) \\
\hline B. cereus RF140 & BLIS & - & $4-9$ & $80 / 30$ & Hydrophobic & Ghanbari et al. (2009) \\
\hline Brevibacillus sp. Gl-9 & Laterosporulin & 5.6 & $2-10$ & $120 / 15$ & No disulfide bridge & Singh et al. (2012) \\
\hline Bacillus sp. strain HIL Y-85 & Mersacidin & - & - & $-/-$ & - & Schmitz et al. (2006) \\
\hline Bacillus sp. MTCC 43 & BLIS & - & $4-10$ & $100 / 10$ & - & Sharma et al. (2009) \\
\hline $\begin{array}{l}\text { Bacillus and Paenibacillus } \\
\text { spp. }\end{array}$ & SRCAM 602; 1580; 37 & $3.9 ; 3.5 ; 3.2$ & $3-9$ & $100 / 15$ & - & Svetoch et al. (2005) \\
\hline Virgibacillus salexigens & BLIS & 5.3 & - & $121 / 15$ & - & Svetoch et al. (2005) \\
\hline
\end{tabular}

Hydrophobic property is determined using nonpolar solvent; presence of disulfide bridge is determined using $\beta$-mercaptoethanol/ dithiothreitol (DTT) BLIS bacteriocin-like inhibitory substance, $M W$ molecular mass, Te temperature, Ti time, IEP isoelectric point

${ }^{a}$ Range stability at that particular condition

2009; Dominguez et al. 2007; Khochamit et al. 2015). Interestingly, temperature and its holding time greatly affect bacteriocins stability. BLIS from $B$. cereus LFBFIOCRUZ 1640 was comparatively less heat resistance $\left(80{ }^{\circ} \mathrm{C}\right.$ for $\left.30 \mathrm{~min}\right)$ than that of BLIS ZED17/DFAR8
(100 ${ }^{\circ} \mathrm{C}$ for $\left.15 \mathrm{~min}\right)$, thus in $\left(100{ }^{\circ} \mathrm{C}\right.$ for $\left.30 \mathrm{~min}\right)$ and amy$\sin \left(100{ }^{\circ} \mathrm{C}\right.$ for $\left.60 \mathrm{~min}\right)$ (Leite et al. 2016; Kaewklom et al. 2013; Xie et al. 2009; Xin et al. 2015; Dehghanifar et al. 2019). It is worthy to take note that the heat resistance of Bacillaceae bacteriocins with respect to time is correlated 
to the amino acid residues, types of bond and arrangement of their molecular structures. Any attempt to heat sterilized the bacteriocins at $121{ }^{\circ} \mathrm{C}$ for $15-20$ min will be futile as none of the bacteriocins could withstand such conditions. This was proven to the fact that Entomocin 110 which was heat resistant could only retain its activity up to $53 \%$ after $20 \mathrm{~min}$ incubation at $121{ }^{\circ} \mathrm{C}$ (Cherif et al. 2008). Similarly, BLIS R75 was stable at $121^{\circ} \mathrm{C}$, for only $10 \mathrm{~min}$ (Sharma et al. 2011). Likewise, BLIS MKU3 was stable at $100{ }^{\circ} \mathrm{C}$ for $10 \mathrm{~min}$, but substantially lost its microbial activity at $121{ }^{\circ} \mathrm{C}$ in 15 min (Kayalvizhi and Gunasekaran 2010). Nevertheless, under refrigerated $\left(4{ }^{\circ} \mathrm{C}\right)$ and normal condition, Bacillaceae bacteriocins are generally very stable (Halimi et al. 2010). But yet, study on suitable formulation and storage condition is an interesting area of study to be explored in the future.

\section{Molecular mass}

Bacillaceae bacteriocins consisted of one or two multiple peptides and their molecular weight can be ranging from 2 to $24 \mathrm{kDa}$. Several B. subtilis studied also produced bacteriocins known as Bac IH7, R75, LFB112 which had molecular weight about 14, 12 and $6.3 \mathrm{kDa}$, respectively (Hammami et al. 2011; Sharma et al. 2011; Xie et al. 2009). It was noted that several bacteriocins with different molecular mass can be produced by the same species, but possibly targeting different rival bacteria present in their adapted environment. It is also not surprising that more than one bacteriocin is needed in order to effectively kill its antagonist. This is due to the fact that different bacteriocins synthesized by one bacterium may have different mechanism of inhibition. Some other bacteriocins from Bacillus sp. also showed small molecular weights $(\leq 10 \mathrm{kDa})$ such as cerein $(8.2 \mathrm{kDa})$, subtilin $(3.5 \mathrm{kDa})$, subtilosin $(3.6 \mathrm{kDa})$, subtilein $(5 \mathrm{kDa})$, BLIS RX7 (5 kDa), penisin $(5 \mathrm{kDa})$, cerein $8 \mathrm{~A}(9 \mathrm{kDa})$ and another BLIS of B. subtilis (9.5 kDa) (Geiger et al. 2017; Bochmann et al. 2015; Flühe et al. 2012; Yang et al. 2002; Dominguez et al. 2007; Baindara et al. 2015). It is worthy to note that bacteriocins of the same molecular weight do not necessarily belong to the same type of bacteriocins as they could be differentiated via genome sequencing. As for bacteriocins of different molecular weight, they can be possibly separated and purified based on their molecular size using size exclusion chromatography method. Nevertheless, solely knowing molecular mass was not enough to obtain high purification factor, if not accompanied with knowledge of cationic/anionic characteristics of the bacteriocins. In the case of its application, molecular size may also play a crucial role in the mechanisms associated with barrier selectivity during drug delivery in vivo. Moreover, because of their very small size, they may penetrate barriers paracellularly across intestinal epithelium.

\section{Solvents and detergents}

Although many bacteriocins are stable in various organic solvent and detergents, they are very sensitive to trichloroacetic acid (TCA) treatment mainly due to its proteinaceous nature (Hatcher et al. 2015). Dithiothreitol (DTT) significantly reduced BLIS H4's antimicrobial activity via disruption of disulfide bonds present in this bacteriocin, but the same treatment did not affect laterosporulin's antimicrobial activity (Singh et al. 2012; Baindara et al. 2016, 2017). BAC-IB17, cerein 8A and entomocin 110 were insensitive to $10 \%(\mathrm{v} / \mathrm{v})$ organic solvents such as DMSO, butanol $(\mathrm{BuOH})$, acetone, ethanol $(\mathrm{EtOH})$, methanol $(\mathrm{MeOH})$ and toluene (Dominguez et al. 2007; Cherif et al. 2008; Ansari et al. 2018). Other bacteriocins were also stable in chloroform (CHL) and hexane may indicate that these bacteriocins do not contain lipid in their structure (Senbagam et al. 2013). Solvent is used in medicinal cutaneous cream or oral drugs formulation, thus stability of previously mentioned bacteriocins in respective solvents indicated that such solvents could be selected as suitable combination for antimicrobial drug formulation. In addition, selection of an appropriate solvent is necessary for solvent extraction process, chromatographic purification (e.g. fractionation of proteins based on its solubility) and to maintain bacteriocin stability. For example, solvent with a certain $\log P$ value showed suitability for certain type of bacteriocin. This can be reasoned out from the fact that bacteriocin hydrophilicity and hydrophobicity of $\mathrm{N}$ - and $\mathrm{C}$-terminus differed from one to another. In this instance, bacteriocin with high hydrophobicity region could be purified using hydrophobic chromatography such as Amberlite XAD-16 via hydrophobic interaction.

The presence of hydrophobic region in bacteriocins is also vitally important against certain bacteria (Rea et al. 2010; Kurata et al. 2019). An irregular distribution of hydrophobicity along an oblique $\alpha$-helical structure may allow a bacteriocin to enter membranes at a narrow angle, thereby disturbing membrane structure and lipid bilayer integrity (Kurata et al. 2019). BLIS NSO2 and BLIS KKU213 had an increase antimicrobial activity in the presence of low concentration of EDTA, but the latter had no increase in term of its activity when subjected at higher concentration of EDTA ( $5 \mathrm{mM}$ ) (Senbagam et al. 2013; Khochamit et al. 2015). Bacteriocins coupled with chelating agent such as EDTA showed synergistic inhibition effect. However, a different study demonstrated that no increase antimicrobial activity of BLIS NS02 when combined with preservative such as sodium lactate and potassium sorbate (Senbagam et al. 2013). On the other hand, activity of BLIS KKU213 was insignificantly affected by the treatment of heavy metals such as $\mathrm{FeCl}_{2}$, $\mathrm{CdCl}_{2}$ and $\mathrm{CuSO}_{4}$ (Senbagam et al. 2013; Khochamit 
et al. 2015). Thus, such characteristic would be advantages in treating iron-infection related disease. Hydrophobicity characteristic of bacteriocins also help them to penetrate into targeted area of infection such as epidermis-dermis skin layer and epithelial gastrointestinal tract system.

\section{Spectrum of microbial inhibition}

Antimicrobial analysis is important for the selection of indicator strain to estimate the productivity of bacteriocins during fermentation as well as for the selection of suitable candidates to treat certain infectious diseases. In general, L. monocytogenes was commonly used as indicator strain. BLIS MKU3 inhibited a broad range of G+ve pathogens, which includes L. monocytogenes and Staphylococcus sp. (Kayalvizhi and Gunasekaran 2010). Laterosporulin, BLIS BS15, BacBS2, Entomocin 110, BLIS KKU213, amysin and BLIS of B. mycoides also inhibited the growth of L. monocytogenes (Khochamit et al. 2015; Cherif et al. 2008; Kaewklom et al. 2013; Perumal et al. 2019). Unlike others, BLIS LFB112 was effective against various clinically relevant $\mathrm{G}+\mathrm{ve} / \mathrm{G}-\mathrm{ve}$ pathogens, including $P$. aeruginosa, E. coli, P. multocida, M. luteus, C. perfringens, S. pullorum, S. bovis and S. aureus (Xie et al. 2009). Several severe infections, due to colonization of biofilms in chronic lung infection of cystic fibrosis patients and infection of catheter-urinary tract are associated with $P$. aeruginosa (Islam et al. 2012; Cotter et al. 2012). Two multidrug-resistant clinical isolates, $S$. aureus IVDC and a phytopathogenic yeast were also inhibited by BLIS LFB112 indicating its potential for further preclinical evaluation (Xie et al. 2009; Cotter et al. 2012). BLIS MTCC 43 was effective against S. aureus and Aeromonas hydrophila where the viability of pathogens decreased considerably (up to 70\%) within $10 \mathrm{~h}$ (Sharma et al. 2009). BLIS BS15 was found active against various clinically important bacterial species such as B. cereus, S. typhi and S. aureus (Alam et al. 2011).

Entomocin 110 had a relatively wide spectrum of microbial inhibition against many Bacillus species while purified Bac IH7 displayed a wide inhibitory bacteriocidal activity towards G+ve/G-ve bacteria and fungal pathogens (Cherif et al. 2008; He et al. 2007; Hammami et al. 2011). Thusin, a two-component lantibiotic consists of Ths $\alpha$, Ths $\beta /$ Ths $\beta^{\prime}$, exhibited remarkably efficient antimicrobial activity against $B$. cereus (cells and spores), $L$. monocytogenes, S. sciuri, E. faecalis and S. pneumoniae (Xin et al. 2016). The previously mentioned bacteriocin showed superior activities against methicillin-resistant Staphylococcus aureus, as compared to that of discovered lantibiotics (e.g. thuricin 4A-4, ticin A4), sactibiotic (e.g. thuricin, cerein) and also antibiotic (e.g. vancomycin), thus serve as a candidate to treat complicated skin and bloodstream infections (Xin et al. 2015, 2016). Understanding the range and level of spectrum inhibition of Bacillaceae bacteriocins will provide guidance in choosing types of bacteriocins which are the most effective against pathogens, but exert minimum inhibition to ordinary microbiota. Bacteriocin thurincin $\mathrm{H}$ and thuricin 439 inhibit the growth of Listeria innocua, which can lead to septic shock caused by cholangitis and potentially be fatal (Wieckowski et al. 2015; Huang et al. 2016).

Recent report also demonstrated that thuricin S, penisin, and geobacillin-l act as pore-forming bacteriocins, as demonstrated by the presence of nonpermeable stain propidium iodide inside the bacterial cells treated by these bacteriocins (Salazar-Marroquín et al. 2016; Garg et al. 2014; Baindara et al. 2015). Although geobacillin-l showed similarity towards inhibition of the transglycosylation step in cell wall biosynthesis, but its mechanism of pore formation differs from that of nisin (Garg et al. 2014). Thuricin S interacts with the cytoplasmic membrane to dissipate the transmembrane polarization potential. Entomocin 110 also poses dual mode of action (e.g. inhibition of cell wall biosynthesis and pore formation) against rival pathogens which has been suggested to explain the reason of continuous microbial susceptibility towards these bacteriocins. On the other hand, BLIS RX7, BLIS MKU3, BLIS NCIMB 3610, BAC-IB17, Bac-SM01, pumilicin-4 and mersacidin have bacteriocidal activity against $S$. aureus (Chhetri et al. 2019; Mickymaray et al. 2018; Ansari et al. 2018; Schmitz et al. 2006; Maria et al. 2012; Kayalvizhi and Gunasekaran 2010). Mersacidin via mersacidin-lipid II binding motif binds to lipid II thus inhibits the transglycosylation step of the cell wall biosynthesis of $S$. aureus (Schmitz et al. 2006). During inhibition process, $\mathrm{Ca}^{2+}$ ions enhance bacteriocidal activity of mersacidin and facilitate the interaction of lantibiotics with the $S$. aureus membrane and with lipid II (Islam et al. 2012; Schmitz et al. 2006; Böttiger et al. 2009). Even though it has been proven effective against pathogens in vitro, their effectiveness against pathogens in vivo is poorly understood. Currently, several attempts have been made to demonstrate their effectiveness and safety to in vivo animal model as well as to human.

\section{Prospect in medicine}

Progress in preclinical studies of several Bacillaceae bacteriocins has proven their promising use in medicine, especially to encounter problem related to the case of multidrug-resistant pathogens. One of the most preclinically studied pathogens is methicillin-resistant Staphylococcus aureus which is responsible for the majority of mastitis, skin and soft tissue infections. The antibiotics are losing their efficacy for treatment of skin and soft tissue infections due to the emerging resistance of methicillin-resistant 
Staphylococcus aureus (Van Staden et al. 2016; Islam et al. 2012). Recently, bacteriocins from Bacillus amyloliquefaciens and Paenibacillus sp. Strain A3 known as amyloliquecidin and penisin, respectively, have been tested against $S$. aureus-induced skin infections in vivo (Van Staden et al. 2016; Baindara et al. 2015). Amyloliquecidin treatments significantly reduced the $S$. aureus infection to a level comparatively similar to that of mupirocin-based ointment treatment as indicated by in vivo bioluminescent imaging (Van Staden et al. 2016). Interestingly, wound closure was pronounced during amyloliquecidin treatment as compared to mupirocin (Van Staden et al. 2016; Islam et al. 2012). In a different case, S. aureus is also often colonizing the anterior nares, and nasal carriage (Ratchaneewan and Pipatsatitpong 2014). In an animal study, it has been reported that mersacidin treatment were effective in controlling pre-colonized methicillin-resistant Staphylococcus aureus as well as eradicating methicillin-resistant Staphylococcus aureus colonization in mouse rhinitis. Upon mersacidin intraperitoneal treatment, the methicillin-resistant Staphylococcus aureus was not detected in kidney, blood, liver, lungs, nasal, spleen and no lesions manifested which indicates its effectiveness and potentially be used in clinical areas (Schmitz et al. 2006; Ratchaneewan and Pipatsatitpong 2014).

Bacteriocin of Bacillaceae species also being tested for bacterial vaginosis, a vaginal infection linked to increased chances of preterm delivery, incidence of sexually transmitted infections and fertility problems which are mainly caused by Gardnerella vaginalis (Cavera et al. 2015). Subtilosin, a bacteriocin from Bacillaceae species, clindamycin and metronidazole showed synergistic effect against Gardnerella vaginalis in multispecies Actinomyces biofilm in terms of fractional inhibitory concentration index (Cavera et al. 2015; Algburi et al. 2015). Current treatments of bacterial vaginosis have been associated with increased resistance as well as detrimental effects on healthy microbiota (Algburi et al. 2015; Flühe et al. 2012).

Bacteriocins of Bacillaceae species are also potent in treating gastrointestinal problems caused by the imbalance of gastrointestinal microbiota (Dreyer et al. 2019). The effectiveness of thuricin $C D$ against the clinical hypervirulent $C$. difficile isolates, makes it a good therapeutic agent to treat gastrointestinal problems associated with C. difficile (Rea et al. 2010; Mathur et al. 2017). The bacteriocins such as kenyacin 404, morricin 269, kurstacin 287, tolworthcin 524 and entomocin 420 from $B$. thuringiensis have also demonstrated positive effect against infectious pathogens in udder tissues as well as for gastrointestinal syndromes, emetic, throat infections, scarlet fever, septicaemia, pneumonia and urinary tract infections (Mathur et al. 2017; Pacheco-Cano et al. 2014; Salazar-Marroquín et al. 2016).
On the other hand, B. amyloliquefaciens RX7 bacteriocin was active against a broad spectrum of bacteria and the fungus $C$. albicans, an opportunistic fungal pathogen that is responsible for cutaneous candidiasis in human (Lim et al. 2016). The untreated candidiasis can spread into bloodstream causing invasive candidiasis. Newly discovered bacteriocin may also be an alternative to steroidbased antifungal medication and treatment to multiple antifungal drug-resistant $C$. auris in the future. Further evaluations in clinical trials are necessary to enforce their application and allow their extensive exploitation as successful therapeutic agents. The application of bacteriocins in medicine is rather complicated as compared in food biopreservation due to different physiological milieu which eventually deactivate bacteriocin and end up to be unsuccessful medication. In clinical trials, major concern would be related to the route of drug delivery, sensitivity of Bacillaceae bacteriocins to proteolytic degradation by intestinal enzymes and their level of efficacy to every infected individual. Certainly, it is more complicated when dealing with blood-related infection. When taken orally, bacteriocin faced problems with proteolytic degradation not just in gastrointestinal, but also in serum, plasma and fresh blood. Their permeability across the highly selective epithelial and vascular endothelial cells before entering into the blood stream is also a concern. Proteolytic enzymes especially serine proteases recognize and cleave C-terminal lysine or arginine and positively charged histidine. Essentially, bacteriocins may also bind to blood cells and plasma proteins. Therefore, many factors have to be considered when it comes to clinical trials such as their effective inhibition dose, pharmacokinetic (absorption, distribution, metabolism and excretion), pharmacodynamic (exposure time) and nonhaemolytic properties. Synergistic effects of several bacteriocins or combination of several drugs and antibiotics as well as encapsulation of protective nanoparticles are some of interesting topics in forthcoming studies.

\section{Wild strains and their origin}

A variety of industrial Bacillaceae species has been granted with GRAS status by the United States Food and Drug Administration (FDA) such as Bacillus subtilis, Bacillus licheniformis and Bacillus pumilus. Some of them such as Bacillus clausii, Brevibacillus laterosporus, Bacillus coagulans and Paenibacillus polymyxa were even marketed as probiotics (Khatri et al. 2016; Khochamit et al. 2015). Bacteriocin from Bacillaceae species is an interesting area of discussion since they have a safe profile history in food-agriculture products and synthesize a great number of peptide antibiotics. Bacillus were isolated and studied from food products such as Thai shrimp paste (Kapi), maari fermented baobab seeds, 
Malaysian-Indonesian fermented fish (budu), honey, fermented chunks of mung bean (Phaseolus radiatus), raw milk and Indian fermented food dal vari. Bacteriocins of Bacillaceae species were also obtained from internal organs such as intestines from the Apis mellifera $L$. bee and intestine of Caspian Frisian Roach. Bacteriocinproducing Bacillus species from natural resources have also been isolated from native woodlands of southern Brazil, rhizosphere of plant, Amazon basin and soil. Faeces sources were also studied such as from water buffalo rumen and cattle. Table 6 summarizes bacteriocin-producing strains from Bacillaceae.

\section{Biomanufacturing}

\section{Inocula size}

Biomanufacturing process utilizes biological systems to produce bacteriocins in large-scale quantity at an economical cost. Most studies utilize one variable at a time (OVAT) approach to analyse factors which influence productivity of a bacteriocin. However, modern statistical approaches using response surface methodology (RSM) and artificial neural network (ANN) have also been reported. Figure 1 shows a variety of environmental factors which regulates biosynthesis and production of bacteriocins in Bacillaceae species that have been identified and extensively studied. These include inocula size, medium composition (carbon, nitrogen, and minerals), temperature, $\mathrm{pH}$, agitation speed and aeration rate. Inocula preparation plays an important role in bacteriocin production where the optimum inocula size is favourable for highest productivity. For instance, $1 \%(\mathrm{v} / \mathrm{v})$ inocula of $B$. velezensis BS2, B. subtilis EMD4 and B. subtilis H27 were prepared in Luria-Bertani broth (LB) medium grown overnight prior to inoculation into the bacteriocin production media such as LB, tryptic soy broth (TSB), nutrient broth (NB), and brain heart infusion (BHI) (Liu et al. 2015; Kindoli et al. 2012; Chopra et al. 2014; Perumal et al. 2019). Likewise, $1 \%(\mathrm{v} / \mathrm{v})$ inocula $\left(1 \times 10^{7} \mathrm{CFU} /\right.$ $\mathrm{mL}$ ) of $\mathrm{B}$. cereus $8 \mathrm{~A}$ obtained in $\mathrm{BHI}$ at $30^{\circ} \mathrm{C}$ were inoculated into $100 \mathrm{~mL}$ of production medium in Erlenmeyer

Table 6 Bacteriocin-producing strains from Bacillaceae

\begin{tabular}{|c|c|c|c|}
\hline Microorganisms & Strains & Origin & References \\
\hline B. subtilis & $\begin{array}{l}\text { BS15, W42, R75, NCIMB 3610, } \\
\text { LFB112, L-Q11 }\end{array}$ & $\begin{array}{l}\text { Soil, Korean traditional fermented } \\
\text { soy food (Cheonggukjang), } \\
\text { fermented chunks of Mung Bean } \\
\text { (Phaseolus radiatus) }\end{array}$ & $\begin{array}{l}\text { Maria et al. (2012), Xie et al. (2009), } \\
\text { Sharma et al. (2011), Alam et al. } \\
\text { (2011), Qin et al. (2019), Lee and } \\
\text { Hwan Kim (2012) }\end{array}$ \\
\hline B. subtilis subsp. subtilis & $\mathrm{H} 4, \mathrm{IH} 7, \mathrm{~F} 1, \mathrm{G} 2, \mathrm{~B} 3, \mathrm{~B} 122, \mathrm{~B} 222$ & $\begin{array}{l}\text { Fermented Hibiscus sabdariffa seed } \\
\text { (bikalga), rhizosphere plants } \\
\text { isolate, fermented baobab seeds } \\
\text { (maari) }\end{array}$ & $\begin{array}{l}\text { Compaoré et al. (2013), Hammami } \\
\text { et al. (2011), Kaboré et al. (2013) }\end{array}$ \\
\hline B. cereus & $\begin{array}{l}\text { NS02, BC7, 8A, GS1, LFB-FIOCRUZ } \\
\text { 1640, ATCC 14579T, HVR22 }\end{array}$ & $\begin{array}{l}\text { Buffalo milk, fermented fish (budu), } \\
\text { soil }\end{array}$ & $\begin{array}{l}\text { Senbagam et al. (2013), Hatcher } \\
\text { et al. (2015), Yusra et al. (2014), } \\
\text { Dominguez et al. (2007) }\end{array}$ \\
\hline B. licheniformis & P40, AnBa9, ZJU12, MKU3, 490/5 & $\begin{array}{l}\text { Aloqt (a crusty dried product made } \\
\text { from goat milk), soil }\end{array}$ & $\begin{array}{l}\text { Cladera-Olivera et al. (2004), He et al. } \\
\text { (2006), Hanafy et al. (2016), Luca } \\
\text { et al. (2002) }\end{array}$ \\
\hline B. thuringiensis subsp. entomocidus & HD9, HD110 & Soil & Cherif et al. (2008) \\
\hline B. thuringiensis subsp. tolworthy & HD125 & Soil & Cherif et al. (2008) \\
\hline B. amyloliquefaciens & $\begin{array}{l}\text { An6, FZB42, ZJHD3-06, RX7, CAMT2, } \\
\text { CMW1 }\end{array}$ & $\begin{array}{l}\text { Soil, marine fish Epinephelus areola- } \\
\text { tus isolate }\end{array}$ & $\begin{array}{l}\text { Scholz et al. (2014), Herzner et al. } \\
\text { (2011), Liu et al. (2013), An et al. } \\
\text { (2015), Kurata et al. (2019) }\end{array}$ \\
\hline B. thuringiensis & $\mathrm{BRC}-\mathrm{ZYR} 2$ & Soil & Huang et al. (2016) \\
\hline B. thuringiensis subsp. tochigiensis & HD868 & Soil & Salazar-Marroquín et al. (2016) \\
\hline B. coagulans & 14 & Soil & Pokusaeva et al. (2009) \\
\hline B. laterosporus & SA 14 & Air & Somsap et al. (2016) \\
\hline B. mycoides & - & Whey & Sharma et al. (2009) \\
\hline B. thuringiensis & B439, F4 & Soil & Salazar-Marroquín et al. (2016) \\
\hline Brevibacillus sp. & Gl-9 & Soil & Singh et al. (2012) \\
\hline B. thuringiensis subsp. thuringiensis & $\mathrm{HD} 2$ & & Salazar-Marroquín et al. (2016) \\
\hline B. megaterium & - & Soil & Antal et al. (2008) \\
\hline Bacillus sp. & RF 140, SP-1-13LM, MTCC 43 & $\begin{array}{l}\text { Soil, intestinal bacterium of Caspian } \\
\text { Frisian Roach }\end{array}$ & $\begin{array}{l}\text { Yusra et al. (2014), Ghanbari et al. } \\
\text { (2009) }\end{array}$ \\
\hline
\end{tabular}




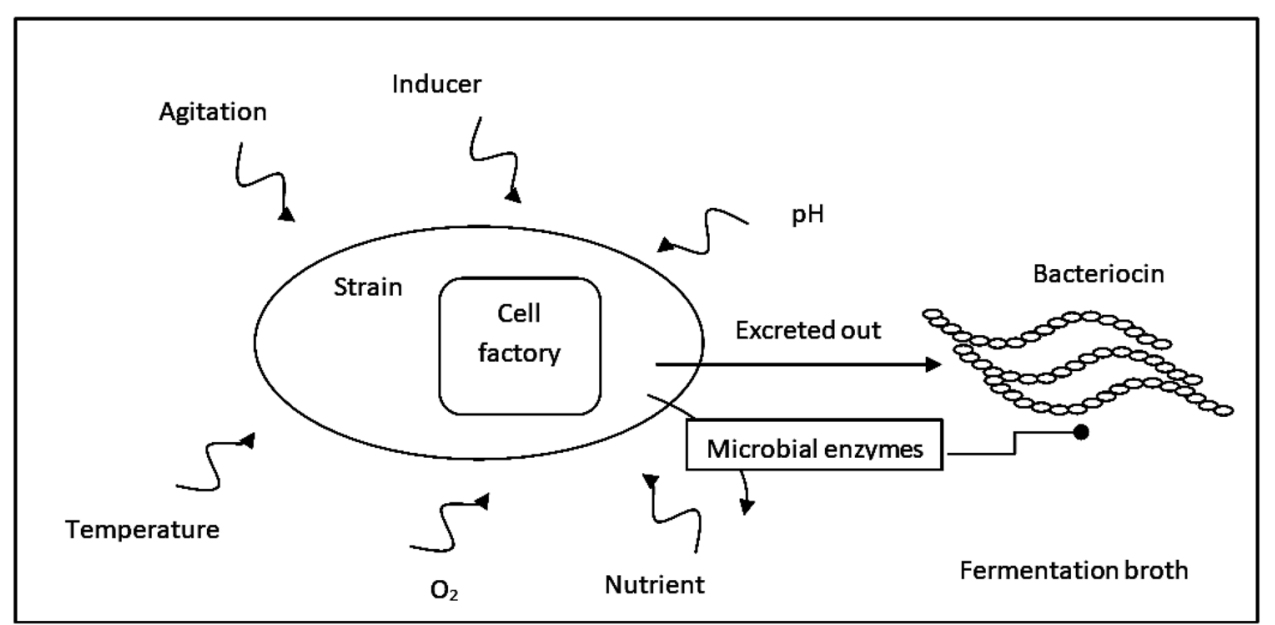

Fig. 1 Interaction of several fermentation factors during bacteriocin production. The cell factory comprised several components such as nucleus, ribosome and enzymes

flasks (Dominguez et al. 2007). In practice, $1-5 \%(\mathrm{v} / \mathrm{v})$ inocula size has been reported as optimal size for maximum bacteriocin production of most strains producer. Very small inocula size will lead to longer production time as compared to optimal inocula size. However, a larger inocula size of $10 \%(\mathrm{v} / \mathrm{v})$ at $1 \times 10^{9}$ cells $/ \mathrm{mL}$ has been reported for $B$. thuringiensis strains prior to inoculation into the TSB production medium (Ovchinnikov et al. 2016; Huang et al. 2016). Higher inocula size may shorten fermentation time but also affect nutrient consumption which may also add cost the production process. The optimum inocula size may vary from strain producers due to their cells proliferation rate, ability to metabolize medium, mass transfers, medium size and nutrient composition. Nonetheless, the minimum inocula size is preferred due to easier inoculation in largescale fermenter, but very low inocula size can affect its productivity. Inocula size is also important for the preparation of seed culture which greatly affect large-scale bacteriocin production. Even though the overnight culture was commonly used as seed culture, the growth of the seed culture curve should be studied, and culture at exponentially phase should be used for the production.

\section{Carbon and nitrogen sources}

Medium and its composition play a vital role for growth and expression of the bacteriocins from various species (Table 7). In many cases, the optimal growth medium does not reflect optimal productivity of bacteriocins by strain producers. Medium composition affects the production of necessary enzymes (e.g. lanthipeptide peptidase, oxidoreductase) for bacteriocin production as well as essential amino acids and organic acid required for its synthesis. In general, nonspecific media such as MRS, M17 and BHI are used to produce bacteriocins due to abundant source of nutrient, carbon, nitrogen, vitamins and minerals. For instance, bacteriocin from strain $B$. subtilis R75, B. amyloliquefaciens SP-1-13LM, Bacillus sp. H27, B. coagulans I4, Bacillus sp. SW1-1, B. cereus SS28 and B. subtilis NS02 were highly produced in multifaceted media such as MRS and BHI (Kim et al. 2014; Senbagam et al. 2013; Yusra et al. 2014; Kaewklom et al. 2013). Highest yield of bacteriocins EMD4 was noted using TSB medium as compared to LB, BHI and NB (Liu et al. 2015; Chopra et al. 2014). Comparatively, bacillocin $\mathrm{Bb}$ was produced in greater amount in $\mathrm{BHI}$ as compared to lactose broth, LB, TSB and NB (Saleem et al. 2009). In contrast, TSB medium were more favourable for the production of entomocin 110, as compared to that of NB, BHI, T3 and Mueller-Hinton (MH) medium (Cherif et al. 2008). Unfortunately, these media are complex, expensive and may contain many unused nutrient at the end of fermentation process which may result in complicated bacteriocin downstream and purification processing. The cost and type of these media are major concerns in bacteriocin production with high yield, yet at an economical price. Complexity of nutrients with high contents of unwanted peptides and pigments could greatly hamper purification process.

Several attempts have been reported to replace the use of complex media with byproducts or lower cost and even simpler medium formulation. In a study, higher bacteriocin $\mathrm{P} 40$ production was achieved in cheese whey medium (CWM) as compared to that of grape bagasse, soybean or feather meal media. Very high bacteriocin P40 production was obtained only at high concentration 
Table 7 Media composition, temperature, pH, agitation speed and fermentation time for the Bacillaceae bacteriocins production

\begin{tabular}{|c|c|c|c|c|c|c|}
\hline Bacteriocins & Medium & Composition (g/L) & $\mathrm{T}\left({ }^{\circ} \mathrm{C}\right)$ & $\mathrm{pH}$ & Agit. (rpm), time (h) & References \\
\hline Elgicins & Synthetic KL medium & $\begin{array}{l}\text { Glucose, } 5 ; \mathrm{CaCl}_{2}, 2 ;\left(\mathrm{NH}_{4}\right)_{2} \mathrm{SO}_{4 \prime} \\
4 ; \mathrm{K}_{2} \mathrm{HPO}_{4}, 2.6 ; \mathrm{MgSO}_{4} \\
\text { 4; } \mathrm{NaCl}_{2} ; \mathrm{FeSO}_{4} \cdot 7 \mathrm{H}_{2} \mathrm{O} \\
0.002 ; \mathrm{ZnSO} \mathrm{OH}_{4} \cdot 7 \mathrm{H}_{2} \mathrm{O}, 0.002 ; \\
\mathrm{MnSO}_{4} \cdot \mathrm{H}_{2} \mathrm{O}, 0.0015\end{array}$ & 30 & 7.2 & 200,120 & Teng et al. (2012) \\
\hline P40 & $\mathrm{BHI}$ & $\begin{array}{l}\text { BIS, 12.5; BHIS, 5.0; } \mathrm{PP}, 10.0 ; \text { glu- } \\
\text { cose, 2.0; } \mathrm{NaCl}, 5.0 ; \mathrm{Na}_{2} \mathrm{PO}_{4}, 2.5\end{array}$ & 30 & 7.4 & 125,48 & Cladera-Olivera et al. (2004) \\
\hline Polyfermenticin & TSB & $\begin{array}{l}\mathrm{PDC}, 17 ; \mathrm{NaCl}, 5 ; \mathrm{PDSM}, 3 ; \mathrm{K}_{2} \mathrm{PO}_{4} \\
2.5 ; \text { dextrose, } 2.5\end{array}$ & 37 & 7.0 & 500,3 & Lee et al. (2001) \\
\hline Tolworthcin 524 & TSB & As mentioned & 28 & 7.2 & 200,24 & Pacheco-Cano et al. (2014) \\
\hline Morricin 269 & TSB & As mentioned & 30 & 8 & 210,24 & Pacheco-Cano et al. (2014) \\
\hline Kenyacin 404 & TSB & As mentioned & 26 & 7.2 & 210,24 & Pacheco-Cano et al. (2014) \\
\hline MKU3 & Synthetic & $\begin{array}{l}\text { Peptone, } 5 \text {; yeast extract, } 2.5 ; \\
\mathrm{NaCl}, 25 ; \mathrm{MgSO}_{4}, 0.01 ; \mathrm{KNO}_{3} \text {, } \\
\text { 8.0; } \mathrm{K}_{2} \mathrm{HPO}_{4}, 0.20 ; \text { sorbitol, } 25\end{array}$ & 30 & 6.0 &,- 15 & $\begin{array}{l}\text { Kayalvizhi and Gunasekaran } \\
\text { (2010) }\end{array}$ \\
\hline RF 140 & TSB & $\begin{array}{l}\mathrm{PDC}, 17 ; \mathrm{NaCl}, 5 ; \mathrm{PDSM}_{1} 3 ; \mathrm{K}_{2} \mathrm{PO}_{4} \\
2.5 ; \text { dextrose } 2.5\end{array}$ & 25 & $7.5(8-9.5)$ &,-- & Ghanbari et al. (2009) \\
\hline An6 & Synthetic & Starch, 20; yeast extract, 10 & 30 & 8.0 & 200,48 & Cavera et al. (2015) \\
\hline $\mathrm{XH} 25$ & Synthetic & Starch, 15.3; $(\mathrm{NH} 4)_{2} \mathrm{SO}_{4}, 46$ & $\sim 30$ & 6.15 &,-- & Ayed et al. (2015) \\
\hline YAS 1 & PYB & $\begin{array}{l}\text { Peptone, } 10 \text {; yeast extract, } 5 \text {; } \\
\text { beef extract, } 3\end{array}$ & 30 & $6.5-7.5$ & 207,62 & Ayed et al. (2015) \\
\hline Bacillocin bb & $\mathrm{BHI}$ & As mentioned & 32 & $\sim 7.0$ &,$- 8-16$ & Saleem et al. (2009) \\
\hline Lichenin & $M-L-10$ & $\begin{array}{l}\text { L-10, glucose, } 0.5 ; 20 \%(\mathrm{w} / \mathrm{v}) \\
\text { inert Thermocol beads }\end{array}$ & 39 & 6.8 &,$- 72-96$ & Pattnaik et al. (2005) \\
\hline NS02 & MRS & $\begin{array}{l}\text { Glucose, } 2 ; \mathrm{C}_{2} \mathrm{H}_{9} \mathrm{NaO}_{5}, 0.5 ; \\
\text { Tween } 80,0.1 ; \mathrm{K}_{2} \mathrm{HPO}_{4}, 0.2\end{array}$ & $\sim 37$ & - &,- 24 & Senbagam et al. (2013) \\
\hline SW1-1 & $\mathrm{BHI}$ & As mentioned & 30 & 7.0 &,- 24 & Kim et al. (2014) \\
\hline Bacillocin 490 & TY & $\begin{array}{l}\text { Tryptone, 16; yeast extract, 10; } \\
\mathrm{NaCl}, 5\end{array}$ & 55 & $\sim 7.0$ &,-- & Luca et al. (2002) \\
\hline EMD4 & TSB & As mentioned & 37 & $\sim 7.0$ & 130,48 & Chopra et al. (2014) \\
\hline $\mathrm{Bac} \mathrm{H} 27$ & $\mathrm{BHI}$ & As mentioned & 37 & - &,- 72 & Compaoré et al. (2013) \\
\hline Sh10 & Synthetic & Tryptone, 2; glucose, 1; $\mathrm{NaCl}, 2$ & 30 & 8 & 200,24 & Shayesteh et al. (2014) \\
\hline Cerein 8A & Synthetic & Soybean protein & 34 & $6.5-9$ & 125,28 & Dominguez et al. (2007) \\
\hline SP-1-13LM & MRS & As mentioned & 37 & - & 200,48 & Kaewklom et al. (2013) \\
\hline Entomocin 110 & TSB & As mentioned & 30 & $\sim 7$ &,$- 16-48$ & Cherif et al. (2008) \\
\hline
\end{tabular}

$T$ temperature, Agit agitation rate, $B \mathrm{HI}$ brain heart infusion, $\mathrm{BIS}$ brain infusion solids, $\mathrm{BHIS}$ beef heart infusion solids, $P P$ proteose peptone, $\mathrm{NaCl}$ sodium chloride, $\mathrm{Na}, \mathrm{PO}$ disodium phosphate, $\mathrm{MgSO}_{4}$ magnesium sulfate, $\mathrm{KNO}_{3}$ potassium nitrate, $\mathrm{K}_{2} \mathrm{HPO}_{4}$ dipotassium hydrogen phosphate, $\mathrm{K}_{2} \mathrm{PO}_{4}$ dipotassium phosphate, $\mathrm{FeSO} \mathrm{O}_{4} \cdot 7 \mathrm{H}_{2} \mathrm{O}$ iron(II) sulfate heptahydrate, $(\mathrm{NH} 4)_{2} \mathrm{SO}_{4}$ ammonium sulfate, $\mathrm{CaCl}_{2}$ calcium chloride, $\mathrm{ZnSO} \mathrm{O}_{4} \cdot \mathrm{HH}_{2} \mathrm{O}$ zinc sulfate heptahydrate, $\mathrm{MnSO}_{4} \cdot \mathrm{H}_{2} \mathrm{O}$ manganese sulfate, $\mathrm{TY}$ tryptone-yeast medium, TSB tryptone soy broth, PDC pancreatic digest of casein, PDSM papaic digest of soybean meal, $P Y B$ peptone yeast beef, MRS de Man-Rogosa-Sharpe, - not mentioned

$(70 \mathrm{~g} / \mathrm{L})$ of CWM which indicates the need of a richnutrient medium (Cladera-Olivera et al. 2004; Garg et al. 2014). However, utilization of concentrated CWM will not only lead to an increase in bacteriocin yield, but also the cost of its production (Cladera-Olivera et al. 2004; Garg et al. 2014). In contrast, cerein $8 \mathrm{~A}$ could be maximally produced with soybean protein at concentration of more than $20 \mathrm{~g} / \mathrm{L}$, comparatively higher than that of soybean-fish meal, industrial fibrous soybean residues and whey cheese protein (Dominguez et al. 2007). Interestingly, the yield of cerein $8 \mathrm{~A}$ in soybean protein was comparable to that obtained in BHI (Dominguez et al. 2007). It was noted that incorporation of small amount of BHI up to $5 \%(\mathrm{w} / \mathrm{w})$ into grinded baobab seeds gave higher BLIS B122, B222 and B3 production as compared to pure $\mathrm{BHI}$, which also could be an alternative approach to reduce the amount of BHI (Kaboré et al. 2013).

The use of other carbon [e.g. glucose, sucrose $\left(\mathrm{C}_{12} \mathrm{H}_{22} \mathrm{O}_{11}\right)$, lactose $\left.\left(\mathrm{C}_{12} \mathrm{H}_{22} \mathrm{O}_{11}\right)\right]$ and nitrogen (e.g. peptone, tryptone) sources have also been reported, but it could only led to low bacteriocins production (Baindara et al. 2015; Kaewklom et al. 2013). For example, amysin 
was barely produced in tryptone as compared to MRS (Kaewklom et al. 2013). Combination of peptone at low concentration and sorbitol could be used for bacteriocin MKU3 production (Kayalvizhi and Gunasekaran 2010). Nevertheless, high yield of lichenin has been successfully produced in modified L-10 medium supplemented with $0.5 \%(\mathrm{w} / \mathrm{v})$ glucose $\left(\mathrm{C}_{6} \mathrm{H}_{12} \mathrm{O}_{6}\right)$ (Pattnaik et al. 2001, 2005). Similarly, bacteriocin $14 \mathrm{~B}$ was produced higher with modified LB medium supplemented with $10 \mathrm{~g} / \mathrm{L}$ glucose as compared to sorbitol, maltose, lactose and sucrose (Hammami et al. 2011). Maximum BLIS An6 was successfully achieved after 48 -h fermentation in a production medium consisted of starch $(20 \mathrm{~g} / \mathrm{L})$ and yeast extract $(10 \mathrm{~g} / \mathrm{L})$ (Ayed et al. 2015). In RSM-optimized condition, yeast extract exerts significant effect on bacteriocin BAC YAS1 and XH25 level, but the former was not influenced by soluble starch and initial pH (Embaby et al. 2014). In an experiment involving several media components [e.g. lactose, ammonium nitrate $\left(\mathrm{NH}_{4} \mathrm{NO}_{3}\right)$, yeast extract and sodium chloride $(\mathrm{NaCl})]$, it was found that substantial high bacteriocin $\mathrm{AnBa} 9$ was produced when yeast extract coupled with $\mathrm{NaCl}$ (Anthony et al. 2009). High penisin production was also achieved using modified medium consisting of nutrient broth, yeast extract and peptone (Baindara et al. 2015). In most cases, organic nitrogen source (e.g. yeast extract) is preferred as compared to inorganic nitrogen source probably due to easy access to nutrient and suitability for cellular metabolism (Cladera-Olivera et al. 2004; Antal et al. 2008). The beef extract $(\mathrm{BE})$ was the preferred organic nitrogen source and led in accelerating the bacteriocin production of $B$. megaterium (Antal et al. 2008).

The needs for certain medium composition for maximum bacteriocins production can be elucidated by the amount and type of amino acids released as the result of the breakdown of medium such as BHI, M17, yeast extract, peptone and tryptone (Antal et al. 2008). As far as bacteriocins primary structure is concerned, specific type of amino acids are required to create specific type of bacteriocins. Some of the amino acid can be synthesized by the cells, but some other amino acid must be acquired through fermentation medium. For instance, glycine $\left(\mathrm{C}_{2} \mathrm{H}_{5} \mathrm{NO}_{2}\right)$ and gystine $\left(\mathrm{C}_{6} \mathrm{H}_{12} \mathrm{~N}_{2} \mathrm{O}_{4} \mathrm{~S}_{2}\right)$ could stimulate the production of certain bacteriocins, while no stimulus effect was observed for alanine $\left(\mathrm{C}_{3} \mathrm{H}_{7} \mathrm{NO}_{2}\right)$, tyrosine $\left(\mathrm{C}_{9} \mathrm{H}_{11} \mathrm{NO}_{3}\right)$ and glutamic acid $\left(\mathrm{C}_{5} \mathrm{H}_{9} \mathrm{NO}_{4}\right)$ (Flühe et al. 2012). The need for enriched media can be explained by the need for energy for ATP drive ABC transport system in the case for lantibiotic. Some strains produce very large quantity of bacteriocins in the presence of fatty acid constituents from medium containing surfactant [e.g. Tween $\left.80\left(\mathrm{C}_{64} \mathrm{H}_{124} \mathrm{O}_{26}\right)\right]$ and glycerol $\left(\mathrm{C}_{3} \mathrm{H}_{8} \mathrm{O}_{3}\right)$ (Compaoré et al.
2013). This can be explained by either the requirement for optimum growth or the needs of fatty acid moiety for the construction of bacteriocins. Contrarily, a very high initial concentration of sucrose only leads to the repression of catabolism and inhibits biosynthesis of bacteriocin in batch fermentation culture (Compaoré et al. 2013; Flühe et al. 2012). Regardless of various medium compositions studied, they share similarity of the need for high protein and amino acids content for the synthesis of bacteriocins. So far there is no single medium composition suitable for the synthesis for all type of bacteriocins.

Unfavourable media components and concentration will only lead to production of, e.g. succinylation (S-entianin) which are less stable with low antimicrobial activity as compared to unsuccinylated bacteriocins (entianin) (Bochmann et al. 2015; Fuchs et al. 2011). The media component and concentration influence the succinylation of subtilin-like lantibiotics and entianin biosynthesis which is modulated by the transition state regulator $\mathrm{AbrB}$ and enzymatic catalysed mechanism occurs in the extracellular or cellular cell membrane (Bochmann et al. 2015).

\section{Minerals}

In a study, De Meo's factional factorial design has been used to determine the effect of several minerals. It was found that $\mathrm{KNO}_{3}$ and $\mathrm{K}_{2} \mathrm{HPO}_{4}$ at low concentration had positive effect on cell growth and bacteriocin MKU3 production. $\mathrm{NaCl}$ at a concentration of $2.5 \%(\mathrm{w} / \mathrm{v})$ considerably reduced cell growth, but significantly increase bacteriocin MKU3 which is probably due to the effect of osmotic stress (Kayalvizhi and Gunasekaran 2010). For elgicins production, the effect of calcium chloride $\left(\mathrm{CaCl}_{2}\right)$, ammonium sulfate $\left[\left(\mathrm{NH}_{4}\right)_{2} \mathrm{SO}_{4}\right]$, dipotassium hydrogen phosphate $\left(\mathrm{K}_{2} \mathrm{HPO}_{4}\right)$, magnesium sulfate $\left(\mathrm{MgSO}_{4}\right), \mathrm{NaCl}$, iron(II) sulfate heptahydrate $\left(\mathrm{FeSO}_{4} \cdot 7 \mathrm{H}_{2} \mathrm{O}\right)$, zinc sulfate heptahydrate $\left(\mathrm{ZnSO}_{4} \cdot 7 \mathrm{H}_{2} \mathrm{O}\right)$ and manganese(II) sulfate monohydrate $\left(\mathrm{MnSO}_{4} \cdot \mathrm{H}_{2} \mathrm{O}\right)$ have been reported (Teng et al. 2012). In particular, the presence of metal ions such as $\mathrm{Fe}^{3+}, \mathrm{Mg}^{2+}$ and $\mathrm{Mn}^{2+}$ positively affects its production (Teng et al. 2012). Concentrations of $\mathrm{Na}^{+}$and $\mathrm{K}^{+}$up to $3 \%(\mathrm{w} / \mathrm{v})$ stimulated the elgicins production, whereas concentrations of $\mathrm{Mg}^{2+}$ above $0.5 \%$ imposed opposite effect (Teng et al. 2012). As for bacteriocin MKU3, $\mathrm{Mg}^{2+}$ at very low concentration of $0.05 \mathrm{~g} / \mathrm{L}$ had negative effect on its production. In general, high concentrations of phosphate ions (e.g. $\mathrm{PO}_{4}{ }^{3-} ; 0.1-$ $0.35 \mathrm{M})$ regulates biologically active molecule such as bacteriocin in several strain producers (Teng et al. 2012; Kayalvizhi and Gunasekaran 2010). Nevertheless, $\mathrm{PO}_{4}{ }^{3-}$ concentration at $0 \%$ led to no cell growth and bacteriocin production. 


\section{Temperature and $\mathrm{pH}$}

In general, fermentation temperature in the range of $29-40{ }^{\circ} \mathrm{C}$ has been reported suitable for bacteriocins production (Patrick et al. 2008). Temperature higher than $40{ }^{\circ} \mathrm{C}$ is mostly unfavourable due to the nature of the strains producer which is mostly mesophiles. The temperature was normally maintained throughout the fermentation to ensure optimum growth and bacteriocins production. However, it has been previously suggested that high bacteriocin production can be obtained at fermentation temperatures lower than that of optimal growth temperature (Patrick et al. 2008). Therefore, optimum temperature for growth could be different from optimum temperature for production. Temperature controlled at optimum level will allow rapid cell proliferation and enhance the synthesis of important enzymes and proteins (e.g. lanthipeptide peptidase and oxidoreductase) which catalyse biosynthesis or modification of biologically active bacteriocins (Patrick et al. 2008). A maximum production of cerein $8 \mathrm{~A}$ was achieved at fermentation temperature of $30{ }^{\circ} \mathrm{C}$ and between $\mathrm{pH} 6.5$ and 9.0 (Dominguez et al. 2007). Slightly different temperature has been reported for maximum yield of tolworthcin 524 which is at $28{ }^{\circ} \mathrm{C}$, BLIS An6 at $30^{\circ} \mathrm{C}$ and cerein $8 \mathrm{~A}$ at temperature between 22 and $34{ }^{\circ} \mathrm{C}$ (Dominguez et al. 2007; Pacheco-Cano et al. 2014; Huang et al. 2016; Ayed et al. 2015). The production of the bacteriocin $\mathrm{Bb}$ obtained at $32{ }^{\circ} \mathrm{C}$ was higher as compared to that of elevated temperature in the range of $37-40{ }^{\circ} \mathrm{C}$ (Saleem et al. 2009). Maximum bacteriocin production by $B$. amyloliquefaciens was also achieved at fermentation temperature between 30 and $37^{\circ} \mathrm{C}$ for $16-18 \mathrm{~h}$. Mesophilic temperature has an advantage for production cost where little requirement is needed for cooling and heating.

The effect of fermentation $\mathrm{pH}$ towards growth and bacteriocin production was based on the initial fermentation $\mathrm{pH}$ and not controlled throughout fermentation time. Initial $\mathrm{pH}$ value is important to give the optimal $\mathrm{pH}$ condition to support active growth of strain producer. Optimal $\mathrm{pH}$ will ensure optimal biological function of macromolecules, thermodynamic force of chemical reactions and electrochemical potential for ATP synthesis. In particular, the $\mathrm{pH}$ of the origin where it was isolated should be considered. As reported in many literatures, a very high or very low $\mathrm{pH}$ milieu is not suitable for bacterial growth and bacteriocin production probably due to the neutrophilic behaviour of strains producer. The imbalance in $\mathrm{H}^{+}$concentration disturbs cell membrane equilibrium and transport systems of ions and nutrient into the cells. Maximum BLIS production by $B$. licheniformis was achieved at initial $\mathrm{pH}$ between 6.5 and 7.5 which is neutral condition (Cladera-Olivera et al. 2004; Kayalvizhi and Gunasekaran 2010). BLIS NS02 reached its maximum activity in MRS broth when the fermentation culture was adjusted to $\mathrm{pH}$ range between 5.5 and 6.5 (Senbagam et al. 2013). In contrast, Cerein 8A was highly produced when initial $\mathrm{pH}$ was set in the range of 6.5-9.0 (Dominguez et al. 2007). Lichenin production was highest at pH 6.8 after 72-96 h incubation (Pattnaik et al. 2005). The highest production of bacteriocin SW1-1 was demonstrated at $30{ }^{\circ} \mathrm{C}$ in $\mathrm{BHI}$ medium when $\mathrm{pH}$ was initially set at 7.0 (Kim et al. 2014). It is worth noting that in RSM-coupled central composite central design, optimization of $\mathrm{pH}$ and temperature significantly increased the production of BLIS AnBa9 by 25 -fold (Anthony et al. 2009). In RSM (factorial design), three determinants were chosen-temperature $\left(25-37{ }^{\circ} \mathrm{C}\right)$, initial $\mathrm{pH}(6-8)$ and soybean concentration-and showed maximum BLIS P34 production (Motta and Brandelli 2008). Full factorial design was also performed for morricin 269 and kenyacin 404 production, whereby optimal parameters were set at $\mathrm{pH} 8,30^{\circ} \mathrm{C}, 210 \mathrm{rpm}$ and $\mathrm{pH} 7.2,26^{\circ} \mathrm{C}, 210 \mathrm{rpm}$, respectively (Martínez-Cardeñas et al. 2012). On the other hand, maximum BLIS An6 was observed in a culture medium with an initial $\mathrm{pH}$ of 8.0 at $30{ }^{\circ} \mathrm{C}$ after $48 \mathrm{~h}$ fermentation (Ayed et al. 2015). As for B. megaterium, a higher amount of bacteriocin production was recorded when it was grown in MRS medium adjusted to an initial $\mathrm{pH}$ of 6.5, as compared to $\mathrm{pH}$ of 4.5 (Antal et al. 2008).

Even though $\mathrm{pH}$ was only set at initial fermentation $\mathrm{pH}$, the $\mathrm{pH}$ profile during fermentation period has been reported in several literatures (Fig. 2). It was noted that $\mathrm{pH}$ value slowly decreases in several hours after inoculation due to rapid bacterial growth rate (Lee et al. 2001). At this stage, Bacillaceae species produce several organic acids such as malic acid, pyruvic acid, acetic acid, citric acid, succinic acid, $\alpha$-ketoglutaric acid, propionic acid and butyric acid (Lee et al. 2001). Pyruvic acid is considered as one of the key intermediates in TCA cycle and Embden-Meyerhof-Parnas (EMP) pathways, and has important function in bacteriocin biosynthesis. Acetic acid resulted in increasing level of purines and pyrimidines which favour plasmid-encoded bacteriocin gene expression (Ge et al. 2019). However, depending on the species and medium composition, the concentration of these organic acids may vary. The concentration of organic acids decreases when bacterial growth almost reached its stationary phase, as indicated by a slight increase in fermentation $\mathrm{pH}$. The optimum $\mathrm{pH}$ condition is important to maintain membrane potential and establish multiple ion gradients across the cytoplasmic membrane (Dominguez et al. 2007). The products released by bacterial cell are important to protect peptides and biological membranes from inactivation or other possible denaturation caused by a mixture of stress environments, including oxidation, dehydration, heat, cold, desiccation and toxic agents (Dominguez et al. 2007). 


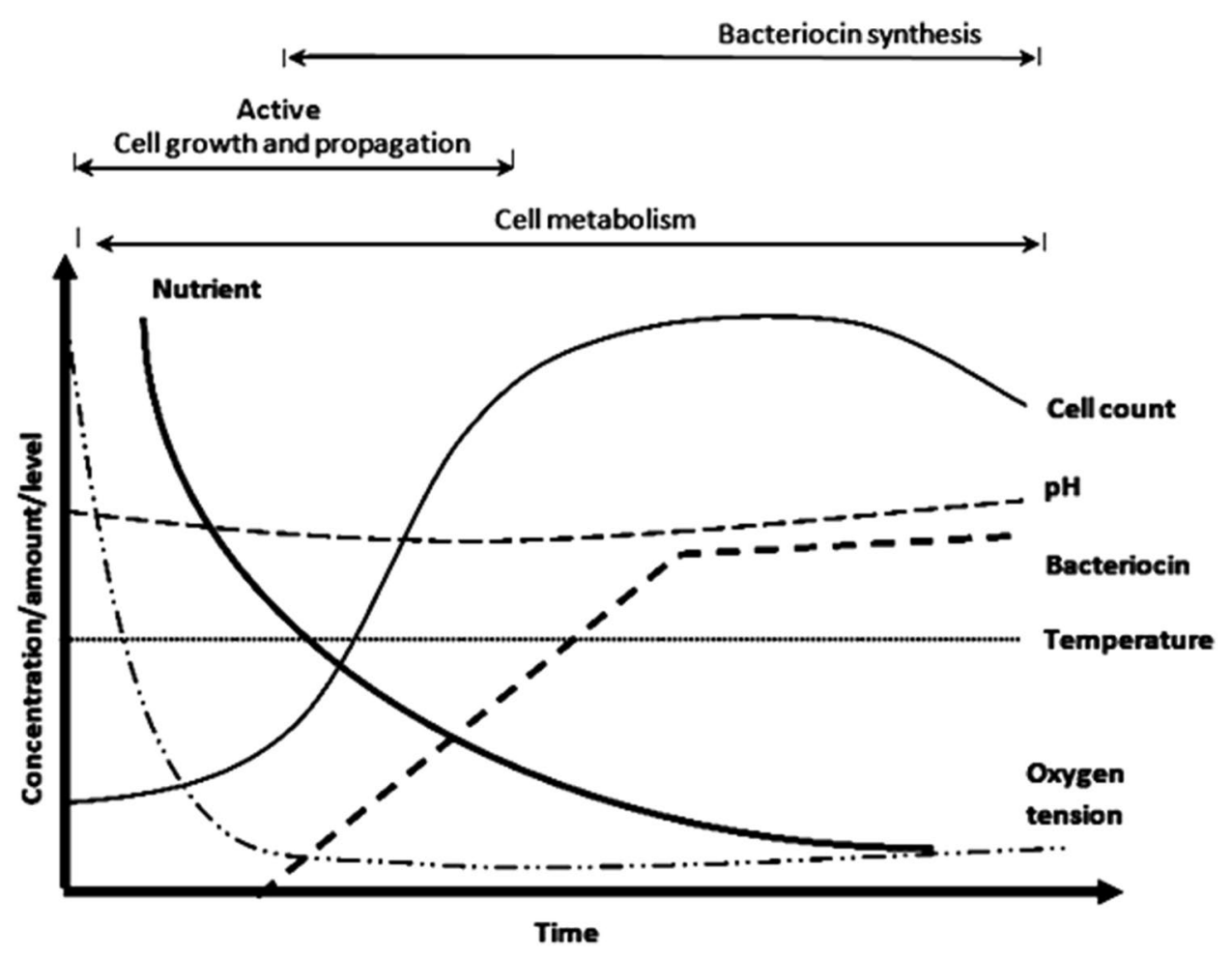

Fig. 2 Typical generalization of fermentation profile of bacteriocins from Bacillaceae based on several research articles and patents

For the production of bacteriocin RF 140, it was noted that the $\mathrm{pH}$ profile of the culture medium was in the range of 8-9.5 (Ghanbari et al. 2009). An increase in $\mathrm{pH}$ during fermentation is often associated with proteolytic enzymes co-produced by strains producer, which could be harmful to some sensitive bacteriocin peptides (Dominguez et al. 2007). Constant yield or even some decrease of the bacteriocin activity in the later stationary growth phase may also indicate that the bacteriocin is relatively sensitive to proteolytic enzymes due to the partial digestion by extracellular proteases released from the cells (Ghanbari et al. 2009; Lee et al. 2001). Only few reports showed that $\mathrm{pH}$ control strategy could be implemented for bacteriocins fermentation. For instance, a simple one-stage $\mathrm{pH}$ control strategy was proposed for the production of polyfermenticin, in which fermentation $\mathrm{pH}$ was controlled at 7 throughout the fermentation process by an addition of acid and base (Lee et al. 2001). The effect of $\mathrm{pH}$ on bacteriocin stability was insignificant due to stability of bacteriocin at wide $\mathrm{pH}$ range. However, unfavorable $\mathrm{pH}$ condition could reduce cell viability by disrupting the stability of the plasma membrane. This is due the presence of excessive $\mathrm{H}^{+}$(due to $\mathrm{pH}$ ) that weakened the membrane permeability barrier, perturbed the membrane lipid bilayers, thus causing leakage of some cellular components, and the dissipation of the electrostatic of the plasma membrane (Dominguez et al. 2007; Lee et al. 2001). So far, uncontrolled pH could be an advantage, neglect the need for acids and bases thus could reduce processing steps and cost for production.

\section{Agitation and aeration rate}

An effective agitation and aeration system is required to supply sufficient oxygen and nutrient in order for strain producer to produce high amount of bacteriocins. A nonagitated condition (e.g. solid-state fermentation technique) could not be implemented as it will only give a very low bacteriocin production. In submerged fermentation technique, the strain producers were heterologously mixed with media components by agitation, fluidization or other mixing means, which eventually increased substrate contact and mass transfer rate. Most studies make use of agitation to increase the production of bacteriocins due to the aerobic or facultative anaerobic nature of producer strains. For instance, high bacteriocin P40 (B. licheniformis) was produced at a relatively low agitation rate of $125 \mathrm{rpm}$ as compared to that of thuricin CD (B. thuringiensis), BLIS R75 (B. subtilis), BLIS (B. mycoides), entianin (B. subtilis), BLIS KKU213 (B. subtilis) and subtilomycin (B. subtilis MMA7) which were aerobically produced at $150 \mathrm{rpm}$ (Rea et al. 2010; Sharma et al. 2011; Phelan et al. 2013; Mathur et al. 2017; Khochamit et al. 
2015). These showed that the production of a bacteriocin can be observed under low agitation and reduced aeration (Kaboré et al. 2013). In shake flask, the aeration was supplied via agitation rate and utilization of an appropriate ratio of working volume per total shake flask volume. Unlike the production of bacteriocins from anaerobic strains, the aerobic strains may require higher aeration to provide sufficient oxygen supply to the microbes especially to support their active initial cell growth. This is probably referring to the production of some bacteriocins such as BLIS An6 (B. amyloliquefaciens), amysin (B. amyloliquefaciens SP-1-13LM), IH7 (B. subtilis), elgicins (Paenibacillus elgii) and tolworthcin 524 (B. thuringiensis) at higher agitation rate of $200 \mathrm{rpm}$ in a rotary shaker (Teng et al. 2012; He et al. 2007; Pacheco-Cano et al. 2014; Kaewklom et al. 2013; Ayed et al. 2015; Hammami et al. 2011).

It is worthy to note that mersacidin of B. amyloliquefaciens FZB42 and penisin of Paenibacillus sp. A3 were also produced at comparatively moderate agitation rate of $180 \mathrm{rpm}$ (Herzner et al. 2011). On the other hand, tiacins production by $B$. cereus was highly achieved when agitated at $220 \mathrm{rpm}$ (Schmitz et al. 2006; Alam et al. 2011; Liu et al. 2013; He et al. 2007). Therefore, aerobic strain such as $B$. amyloliquefaciens may requires high agitation rate in shake-flask fermentation ranging from 180 to $200 \mathrm{rpm}$ as compared to typical facultative anaerobe $B$. licheniformis (Somsap et al. 2016; Cladera-Olivera et al. 2004; Liu et al. 2013; Kayalvizhi and Gunasekaran 2010). In fermenter, aeration rate could be controlled via rotameter or flow meter. In particular, 1-3 vessel volumes per minute (vvm) have been used for bacteriocin production in 2- to 80-L fermenter (Lee et al. 2001; Arias et al. 2013). This control strategy using aeration rate was important especially for aerobic strains. For instance, production of bacteriocin from B. polyfermenticus SCD was supplied with aeration rate of $1 \mathrm{vvm}$ (Lee et al. 2001). On the other hand, the production of lichenin, by $B$. licheniformis 26L-10/3RA was conducted in a totally anaerobic condition in glove box (Garg et al. 2014; Pattnaik et al. 2005). Agitation and aeration rate were also significant factors for high bacteriocin production especially in submerged fermentation. Most studies on Bacillaceae bacteriocins were conducted at shake-flask level where scalability for mass scale production is difficult. Apparently, these parameters studied in shake flask could be different from one conducted in bioreactors due to geometrical difference. Studies conducted in bioreactors are more relevant for large-scale production using known scaling-up procedures.

\section{Dissolved oxygen tension (DOT)}

Oxygen tension is a significant factor for any aerobic fermentation. It could substantially influence cellular metabolism, number of cells, biomass, morphology, electron transport, biochemical interaction, ATP availability, stress-response and even bacteriocin peptides production of some strain producers. The association between oxygen mass transfer and bacteriocin productivity has been a main point in aerobic fermentation and, hence optimization of DOT level is essential for industrial biomanufacturing process. In shake flask, the DOT level cannot be set to a certain level due to the absence of some components such as DO probe and air inlet. In bioreactor, DOT level can be manipulated by controlling either one or both agitation and aeration rate via cascade operating mode. The influence of DOT for bacteriocin production by Bacillaceae species was rarely reported and studied. This is probably due to most of strain producers appear to be facultative anaerobes which had low biological oxygen demand, thus oxygen factor was more or less insignificant (Alam et al. 2011; Schmitz et al. 2006; Liu et al. 2013; He et al. 2007). The DOT fermentation profile was also rarely reported, as most of the studies were mostly conducted in small-scale shake flask. Nevertheless, the effect of DOT on the production of bacteriocin Lincocin PO1 in 10-L bioreactor has been reported in patent. The fermentation DOT profile of strain producer (Bacillus lentus) was high at $0 \mathrm{~h}$ fermentation time, but eventually decreasing from $2 \mathrm{~h}$ onwards (Pohilenko et al. 2014). In uncontrolled DOT milieu, DOT was significantly high at initial fermentation time, but slowly decreases due to active bacterial growth. At its stationary phase, the DOT value fluctuates between 0 and 10\% DOT level indicated that oxygen was only scarcely consumed by the bacterial strains and the oxygen presence was only due to the agitation from the impeller. In DOT-controlled strategy, $B$. lentus bacteriocin was optimally produced via controlling DOT to about $100 \%, 50 \%$ and $10 \%$ at three fermentation stages of 0,20 and $35 \mathrm{~h}$, respectively (Pohilenko et al. 2014). The bacteriocin was produced at low DOT level in the medium, explained that oxidative tension caused an increase of bacteriocin production. In general, most of the Bacillaceae bacteriocin production study does not require high DOT level, probably due to facultative anaerobe nature of most producing strains (Pohilenko et al. 2014). Low DOT for the production of Bacillaceae bacteriocin decreases its dependence on high agitationaeration rate and air compressors, hence lower cost of electricity and this could be another advantage over LAB bacteriocin production. 


\section{Fermentation time}

Fermentation time is important for inocula preparation, seed culture preparation and harvesting time when maximum production has been achieved (Fig. 2). Based on fermentation profile reported in literatures, high bacteriocin production could be obtained as early as within 24 h (Scholz et al. 2014; Baindara et al. 2015; Fuchs et al. 2011; Pohilenko et al. 2014; Kim et al. 2014). Production time can go up to several days, mainly depending on their metabolic character (primary or secondary) and type of bacteriocins. In RSM-optimized fermentation condition, it was found that highest bacteriocin HJDA32 could be obtained using inocula size of $4 \%$ at $\mathrm{pH} 5.3$, agitation rate of $147 \mathrm{rpm}$ and temperature of $30{ }^{\circ} \mathrm{C}$ for $30 \mathrm{~h}(\mathrm{Hu}$ et al. 2014). Sequential statistical approach using Plackett-Burman coupled with RSM (Box-Behnken) was successfully employed whereby optimization of key variables [yeast extract $(0.48 \%(\mathrm{w} / \mathrm{v})$, fermentation time $(62 \mathrm{~h})$ and agitation rate $(207 \mathrm{rpm})]$ in peptone-yeast-beef based medium enhanced 1.6-fold BAC YAS 1 production (Embaby et al. 2014). In RSM ( $2^{3}$ factorial design), three determinants chosen [temperature $\left(26-37{ }^{\circ} \mathrm{C}\right)$, initial $\mathrm{pH}(6.5-7.5)$ and whey concentration $(70 \mathrm{~g} / \mathrm{L})]$ showed maximum bacteriocin production at $15 \mathrm{~h}$ fermentation time (Cladera-Olivera et al. 2004). On the other hand, production time of tolworthcin 524 from B. amyloliquefaciens and BLIS An6 from Bacillus sp. was at $24 \mathrm{~h}$ and 48 h, respectively (Pacheco-Cano et al. 2014; Huang et al. 2016; Ayed et al. 2015). Maximum bacteriocin yield in a culture may be achieved at different growth phases. The production of bacteriocins by $B$. brevis $\mathrm{Bb}$ started during beginning of exponential growth phase and consistently increased up to late stationary phase (Saleem et al. 2009). In particular, maximum production of bacillocin $\mathrm{Bb}$ was achieved after $9 \mathrm{~h}$ of fermentation time (Saleem et al. 2009). Similarly, the production of cerein $8 \mathrm{~A}$ was started at early exponential phase and continued till stationary phase (Dominguez et al. 2007). In comparison, maximum production of cerein produced by Bacillus cereus and tochicin produced by Bacillus thuringiensis subsp tochigiensis were detected at early exponential phase with their production becoming stagnant and eventually declined during the stationary phase (Salazar-Marroquin et al. 2016; Dominguez et al. 2007). Other bacteriocins was secreted in the middle (e.g. entomocin 110) or late exponential phase (e.g. cerein 8A, amysin, BLIS BS15, penisin, Bt BRC-ZYR2) reaching its utmost production at the early and during stationary phase (Dominguez et al. 2007; Cherif et al. 2008; Alam et al. 2011; Kaewklom et al. 2013; Huang et al. 2016). At some point during stationary phase, the bacteriocin produced by the bacterial strain in the medium reached a saturation point. It could be possibly due some factors which limit its production such immunity protein and organic acids, whereby its concentration was maintained at certain level. In bacteriocin immunity mechanisms, an immunity gene is dedicated to produce immunity protein in which its binding to the target bacteriocin can prevent pore formation. In a case of a very high bacteriocin concentration but low amount of immunity protein, the strain producer may also be susceptible to its own bacteriocin (Dominguez et al. 2007; Ayed et al. 2015). Another possibility may be also associated with limited number of multidrug transporter protein. This protein has been proposed as another form of immunity as well as extruding bacteriocin from its production site (cytoplasm) to extracellular medium (Joseph et al. 2013; Scholz et al. 2014; Kurata et al. 2019). A decrease in bacteriocins production may also be caused by cell lysis and proteolytic degradation by nonspecific proteases. However, some bacteriocins produced by Bacillaceae species such as coagulin I4 and cerein $8 \mathrm{~A}$ are often more resistant to extracellular proteases (Dominguez et al. 2007; Hyronimus et al. 1998). Prolonged fermentation process may not only result in an increase in the production expenditure, but may also affect overall yield and productivity as bacteriocins possibly bind onto the surface of the dead cell of strain producer. Most studies showed a good cell growth relationship with bacteriocin production. Nevertheless, a very high cell growth does not always lead to high levels of production.

\section{Inducers}

In nature, bacteriocin could act as an inducer of its own biosynthesis such as auto-induction of mersacidin (Schmitz et al. 2006). Subtilin which consists of 32 amino acids is also capable to automatically induce its own synthesis in a very specific way (Geiger et al. 2017; Bochmann et al. 2015; Spieß et al. 2015). For example, two-element SpaRK system in B. subtilis is specifically activated by Subtilin. Findings also revealed that bacteriocins production was also regulated by induction of sporulation. For instance, the production of bacteriocin by $B$. subtilis was induced when sporulation occurs at 72 and $96 \mathrm{~h}$ due to unfavourable growth conditions and changes in medium composition level (Garg et al. 2014). On the other hand, the addition of either saw dust $(1 \%, \mathrm{w} / \mathrm{v})$ or straw powder $(1 \%, \mathrm{w} / \mathrm{v})$ and Thermocol beads $(20 \%, \mathrm{w} / \mathrm{v})$ into the medium substantially increased the lichenin production by up to 35\% (Garg et al. 2014; Pattnaik et al. 2005). Insertion of Thermocol beads increased the availability of surface area for attachment and subsequent growth of the B. subtilis or contact regulation of lichenin production (Garg et al. 2014; Pattnaik et al. 2005). Other type of beads could possibly be used such as absorbent (e.g. Amberlite XAD-1180) for absorption of charged 
or hydrophobic bacteriocins in situ, which could possibly trigger bacteriocin production. This is especially relevant in the case considering bacteriocin concentration in fermentation medium as one of the limiting factors to its further production. Other approach using Bacillus cereus 183 as an inducer has also been reported whereby it considerably increased bacteriocin production of $B$. thuringiensis at fermentation condition controlled at $28{ }^{\circ} \mathrm{C}, 180 \mathrm{rpm}$ and $\mathrm{pH}$ 7.2. The inoculation of several other rival bacteria could possibly trigger strain producer to produce more bacteriocins in order to maintain their survival in such environment. Other possible oxogenous inducers such as carbon dioxide, Tweens, glycerol, pyruvic acid, amino acid, ketoglutaric acid and acetic acid could also enhance bacteriocin production. The knowledge and determination of factors responsible for bacteriocin production can assist in increasing its production and lowering cost of production.

\section{Bioreactors and mode of operation}

Most bacteriocin fermentation study was conducted using shake flask which was not scalable for mass industrial production. The effects of bioreactor designs (e.g. stirred tank, air-lift, bubble column), fermentation techniques (e.g. submerged, solid state, surface cultures) and modes of bioreactor operation (e.g. batch, fed-batch, continuous) are rarely explored with only few studies have been reported in literature. Nevertheless, the use of a 5-L stirred tank bioreactor (STB) for the production of polyfermenticin has been performed under submerged mode of operation (Lee et al. 2001). In this study, B. polyfermenticus SCD was initially cultivated in $30-60 \mathrm{~mL}$ TSB before the $1-2 \%(\mathrm{v} / \mathrm{v})$ inocula was transferred into the 3 L TSB medium, agitated at $500 \mathrm{rpm}$ for about $24 \mathrm{~h}$. Interestingly, an attempt to produce amylolysin in large-scale has been employed in 80-L STB using strain RFB136, whereby fermentation conditions were controlled at $37^{\circ} \mathrm{C}, 200 \mathrm{rpm}$ for $10 \mathrm{~h}$ (Arias et al. 2013). In fact, several parameters could be properly studied and controlled such as temperature, $\mathrm{pH}$, agitation and aeration rate for bacteriocin production (Lee et al. 2001). Nevertheless, the prominent advantage of production study of bacteriocins using bioreactor is ease of scalability. The optimum experimental conditions in lab-scale bioreactor (e.g. 2-5 $\mathrm{L}$ working volume) which was obtained using OVAT, RSM or ANN approaches could be used for mass production in pilot and even bigger-scale bioreactors. Nevertheless, there are still few reports on feasibility to enhance Bacillaceae production via other bioreactor design such as airlift. Particularly, the production of bacteriocins are mostly studied using STB, in which it provides sufficient with desired mixing pattern using different impeller designs (e.g. Rushton turbine, concave disc) for submerged fermentation. On the other hand, most modes of operation used are batch mode of operation. Although successful bacteriocin production via batch has been demonstrated, this mode suffers several disadvantages such as it requires repetition of process loading and unloading of fermentation medium at every stage as compared to fed-batch or continuous mode of operation.

\section{Bioengineering}

The simplification of biomanufacturing procedures are warranted for bacteriocin production where cost of the media and overall fermentation steps plays a significant role. Substantially high bacteriocins yield are also important prior to downstream processing as low concentration yield is not practicable to be purified probably due to further yield losses which occurred during bacteriocin purification process. Most studies on the Bacillaceae production use wildtype bacteria as the producing strains. In previous years, bacteriocins have been genetically engineered with the development of mutants (e.g. Pseudomycoicidin), recombinant fusion bacteriocins (e.g. sonorensin) and new expression system, but studies were centred on the improvement of the expression level via enhancement of mRNA stability as well as to understand the correlation of their molecular structure and biological activity (Nagao et al. 2011). Genes involved in the production of the mature (active) peptide can be identified and cloned due to their ribosomal synthesis feature. However, analysis of their stability and productivity at large scale (e.g. in bioreactor) are rarely exploited (Nagao et al. 2011; Basi-Chipalu et al. 2015). In a study, high homologous expression of thuricin $\mathrm{H}$ has been successfully developed using newly constructed expression vector pGW133 on the basis of the E. coli-B. thuringiensis shuttle vector pHT315 (Wang et al. 2014a). Efficient and high bioproduction of lantibiotics via bioengineering at small scale has been reported, but deemed for further improvement (Spieß et al. 2015). In another study, a bacteriocin gene has been successfully cloned into vector pET101/D-TOPO, introduced into E. coli BL21 (DE) to heterologously express amylocyclicin CMW1 (Kurata et al. 2019). In such system, IPTG has been used as an inducer while changing growth temperature from 37 to $20{ }^{\circ} \mathrm{C}$ has been suggested for its production. Very little attention has been given to study their mass production in such system. However, a very recent attempt has been reported to produce bacteriocin in larger scale using heterologous expression system. Peocin, a bacteriocin produced by Paenibacillus ehimensis was cloned into pET-28b and transforming E. coli BL21 (DE3) to produce a recombinant peocin (Tseng et al. 2019). The production of previously mentioned bacteriocin was performed under fed-batch mode, utilizing glucose as carbon source, while other parameters such as temperature, agitation and aeration were maintained at $30{ }^{\circ} \mathrm{C}, 500-900 \mathrm{rpm}$ 
and $3 \mathrm{~L} / \mathrm{min}$, respectively (Tseng et al. 2019). In choosing an expression system, there is a concern on the success rate since the genes in gene cluster are essential for the biosynthesis and maturation of the certain bacteriocin and could not be expressed in E. coli. Utilization of a suitable vector and foreign host could be further developed in the future via bioengineering, but complex nature of its production is not easily manipulated and could be very challenging, commonly resulting in nonfunctional proteins. Likewise, many studies showed that phylogenetic divergence between the host and strain producer makes production of heterologous bacteriocins more difficult (Basi-Chipalu et al. 2015; Spieß et al. 2015). Alternatively, an efficient bioengineered production and functional expression of bacteriocin synthetic genes could be done heterologously by yeasts. The design of novel successful genetic manipulation for functional expression of bacteriocins by yeasts would be advantageous. Bioengineered bacteriocins with less impurity could also be a solution to problems with multiple separation steps and low yield of many bacteriocins. Knowledge to date on bacteriocins production enables improved process predictability and duration in which simplification of the process will greatly ride overall bacteriocins biomanufacturing processes.

\section{Conclusion}

Bacteriocins from Bacillaceae species may be some of few solutions for drug-resistant pathogens which ultimately reduce the need for steroid-based medicinal drugs. Members of Bacillaceae are recognized as GRAS and the safety (e.g. nontoxic and nonhemolytic) of these bacteriocins was recently supported by in vitro and in vivo studies. Biochemical characterization of these bacteriocins also showed that they are thermostable and resistant to different enzymes, $\mathrm{pH}$ and solvents which are important for their criteria of selection for medicine, downstream processing and commercial feasibility (e.g. storage, lifespan and drug formulation). Because chemical synthesis of peptides such as bacteriocins are not easily developed, many studies have been devoted to investigate the most desirable and beneficial fermentation process for industrial production of bacteriocins. Studies on the optimized fermentation strategy (e.g. microbes, media, minerals, temperature, $\mathrm{pH}$, agitation rate, aeration rate, DOT) could be used as a guideline for high production of commercial bacteriocins in industrial large-scale bioreactor. In general, fermentation temperature of about $30{ }^{\circ} \mathrm{C}$ with low agitation rate gives highest bacteriocin yield. It can also be concluded that BHI media are the preferred nutrient sources for bacteriocin production by many Bacillaceae species and it showed great affinity specifically towards glucose as carbon source. In the future, bioengineering approach could possibly be used as an alternative to Bacillaceae bacteriocins production although practicability is currently limited to certain lantibiotics.

\begin{abstract}
Abbreviations
LAB: Lactic acid bacteria; GRAS: Generally recognized as safe; MRSA: Methicillin-resistant Staphylococcus aureus; EHEC: Enterohemorrhagic Escherichia coli; VRE: Vancomycin-resistant enterococci; G-ve: Gram negative; G+ve: Gram positive; CDAD: Clostridium difficile-associated disease; FDA: Food and Drug Administration; TOMMs: Thiazole/oxazole-modified microcins; ABC ATP-binding cassette; BLIS: Bacteriocin-like inhibitory substance; IEP: Isoelectric point; CRS: Cellulose-rich solid.
\end{abstract}

\section{Acknowledgements}

Thanks to Prof. Dr. Arbakariya B. Ariff from Bioprocessing and Biomanufacturing Research Center for his guidance in fermentation process. Special thanks to Ms. Noor Hanis Ismail, a graduate in Pharmacy from Manchester University, United Kingdom, for her kindness in English and grammar editing.

\section{Authors' contributions}

AFBL conceived and designed the review paper. The author read and approved the final manuscript.

\section{Funding}

Not applicable.

Availability of data and materials

Not applicable.

Ethics approval and consent to participate

Not applicable.

Consent for publication

Not applicable.

Competing interests

The author declares no competing interests.

\section{Author details}

${ }^{1}$ Department of Bioprocess Technology, Faculty of Biotechnology and Biomolecular Sciences, Universiti Putra Malaysia, 43400 UPM Serdang, Selangor, Malaysia. ${ }^{2}$ Institute of Bioscience, Universiti Putra Malaysia, 43400 UPM Serdang, Selangor, Malaysia.

Received: 14 October 2019 Accepted: 27 January 2020

Published online: 19 February 2020

\section{References}

Alam SI, Kamran M, Sohail M et al (2011) Partial characterization of bacteriocin like inhibitory substance from Bacillus BS15, a local soil isolate. Pak J Bot 43:2195-2199

Algburi A, Volski A, Chikindas ML (2015) Natural antimicrobials subtilosin and lauramide arginine ethyl ester synergize with conventional antibiotics clindamycin and metronidazole against biofilms of Gardnerella vaginalis but not against biofilms of healthy vaginal lactobacilli. Pathog Dis 73:1-12. https://doi.org/10.1093/femspd/ftv018

An J, Zhu W, Liu Y et al (2015) Purification and characterization of a novel bacteriocin CAMT2 produced by Bacillus amyloliquefaciens isolated from marine fish Epinephelus areolatus. Food Control 51:278-282. https://doi. org/10.1016/j.foodcont.2014.11.038

Ansari A, Zohra RR, Tarar OM et al (2018) Screening, purification and characterization of thermostable, protease resistant Bacteriocin active against methicillin resistant Staphylococcus aureus (MRSA). BMC Microbiol 18:192. https://doi.org/10.1186/s12866-018-1337-y

Antal K, Balikó G, Chuluunbaatar T et al (2008) Cloning and characterization of the DNA region responsible for megacin A-216 production in Bacillus megaterium 216. J Bacteriol 190:6448-6457. https://doi.org/10.1128/ JB.00557-08 
Anthony T, Rajesh T, Kayalvizhi N, Gunasekaran P (2009) Influence of medium components and fermentation conditions on the production of bacteriocin(s) by Bacillus licheniformis AnBa9. Bioresour Technol 100:872-877. https://doi.org/10.1016/j.biortech.2008.07.027

Arias AA, Ongena M, Devreese B et al (2013) Characterization of amylolysin, a novel lantibiotic from Bacillus amyloliquefaciens GA1. PLoS ONE 8:e83037. https://doi.org/10.1371/journal.pone.0083037

Ayed HB, Maalej H, Hmidet N, Nasri M (2015) Isolation and biochemical characterisation of a bacteriocin-like substance produced by Bacillus amyloliquefaciens An6. J Glob Antimicrob Resist 3:255-261. https://doi. org/10.1016/j.jgar.2015.07.001

Baindara P, Chaudhry V, Mittal G et al (2015) Characterization of the antimicrobial peptide penisin, a class la novel lantibiotic from Paenibacillus sp. strain A3. Antimicrob Agents Chemother 60:580-591. https://doi. org/10.1128/AAC.01813-15

Baindara P, Singh N, Ranjan M et al (2016) Laterosporulin10: a novel defensin like Class Ild bacteriocin from Brevibacillus sp. strain SKDU10 with inhibitory activity against microbial pathogens. Microbiology 162:1286-1299. https://doi.org/10.1099/mic.0.000316

Baindara P, Gautam A, Raghava GPS, Korpole S (2017) Anticancer properties of a defensin like class IId bacteriocin laterosporulin 10. Sci Rep 7:46541. https://doi.org/10.1038/srep46541

Barbosa J, Caetano T, Mendo S (2015) Class I and Class II lanthipeptides produced by Bacillus spp. J Nat Prod 78:2850-2866. https://doi. org/10.1021/np500424y

Basi-Chipalu S, Dischinger J, Josten M et al (2015) Pseudomycoicidin, a class II lantibiotic from Bacillus pseudomycoides. Appl Environ Microbiol 81:3419-3429. https://doi.org/10.1128/AEM.00299-15

Bastos MC, Lívio M, Coelho V et al (2017) Resistance to bacteriocins produced by Gram-positive bacteria. Microbiology 161:683-700. https://doi. org/10.1099/mic.0.082289-0

Begley M, Cotter PD, Hill C, Ross RP (2009) Identification of a novel twopeptide lantibiotic, lichenicidin, following rational genome mining for LanM proteins. Appl Environ Microbiol 75:5451-5460. https://doi. org/10.1128/AEM.00730-09

Bochmann SM, Spieß T, Kötter P, Entian K-D (2015) Synthesis and succinylation of subtilin-like lantibiotics are strongly influenced by glucose and transition state regulator AbrB. Appl Environ Microbiol 81:614-622. https:// doi.org/10.1128/AEM.02579-14

Böttiger T, Schneider T, Martínez B et al (2009) Influence of $\mathrm{Ca}^{2+}$ ions on the activity of Lantibiotics containing a Mersacidin-like lipid II binding motif. Appl Environ Microbiol 75:4427-4434. https://doi.org/10.1128/ AEM.00262-09

Cavera VL, Volski A, Chikindas ML (2015) The natural antimicrobial subtilosin A synergizes with lauramide arginine ethyl ester (LAE), $\varepsilon$-poly-L-lysine (polylysine), clindamycin phosphate and metronidazole, against the vaginal pathogen Gardnerella vaginalis. Probiotics Antimicrob Proteins 7:164-171. https://doi.org/10.1007/s12602-014-9183-1

Cherif A, Rezgui W, Raddadi N et al (2008) Characterization and partial purification of entomocin 110, a newly identified bacteriocin from Bacillus thuringiensis subsp. Entomocidus HD1 10. Microbiol Res 163:684-692. https://doi.org/10.1016/j.micres.2006.10.005

Chhetri V, Prakitchaiwattana C, Settachaimongkon S (2019) A potential protective culture; halophilic Bacillus isolates with bacteriocin encoding gene against Staphylococcus aureus in salt added foods. Food Control 104:292-299. https://doi.org/10.1016/j.foodcont.2019.04.043

Chopra L, Singh G, Choudhary V, Sahoo DK (2014) Sonorensin: an antimicrobial peptide, belonging to the heterocycloanthracin subfamily of bacteriocins, from a new marine isolate, Bacillus sonorensis MT93. Appl Environ Microbiol 80:2981-2990. https://doi.org/10.1128/AEM.04259-13

Cladera-Olivera F, Caron GR, Brandelli A (2004) Bacteriocin production by Bacillus licheniformis strain P40 in cheese whey using response surface methodology. Biochem Eng J 21:53-58. https://doi.org/10.1016/j. bej.2004.05.002

Collins FWJ, O'Connor PM, O'Sullivan O et al (2016) Formicin—a novel broadspectrum two-component lantibiotic produced by Bacillus paralicheniformis APC 1576. Microbiology 162:1662-1671. https://doi.org/10.1099/ mic. 0.000340

Compaoré CS, Nielsen DS, Ouoba LIl et al (2013) Co-production of surfactin and a novel bacteriocin by Bacillus subtilis subsp. subtilis $\mathrm{H} 4$ isolated from Bikalga, an African alkaline Hibiscus sabdariffa seed fermented condiment. Int J Food Microbiol 162:297-307. https://doi.org/10.1016/j. ijfoodmicro.2013.01.013

Cotter PD, Ross RP, Hill C (2012) Bacteriocins—a viable alternative to antibiotics? Nat Rev Microbiol 11:95-105. https://doi.org/10.1038/nrmicro2937

Dehghanifar S, Keyhanfar M, Emtiazi G (2019) Production and partial purification of thermostable bacteriocins from Bacillus pumilus ZED17 and DFAR8 strains with antifungal activity. Mol Biol Res Commun 8:41-49. https://doi.org/10.22099/mbrc.2019.31563.1367

Dischinger J, Josten M, Szekat C et al (2009) Production of the novel twopeptide lantibiotic lichenicidin by Bacillus licheniformis DSM 13. PLoS ONE 4:e6788. https://doi.org/10.1371/journal.pone.0006788

Dominguez APM, Bizani D, Cladera-Olivera F, Brandelli A (2007) Cerein 8A production in soybean protein using response surface methodology. Biochem Eng J 35:238-243. https://doi.org/10.1016/j.bej.2007.01.019

Dreyer L, Smith C, Deane SM et al (2019) Migration of bacteriocins across gastrointestinal epithelial and vascular endothelial cells, as determined using in vitro simulations. Sci Rep. https://doi.org/10.1038/s41598-01947843-9

Embaby AM, Heshmat Y, Hussein A, Marey HS (2014) A sequential statistical approach towards an optimized production of a broad spectrum bacteriocin substance from a soil bacterium Bacillus sp. YAS 1 Strain. Sci World J. https://doi.org/10.1155/2014/396304

Field D, Cotter PD, Hill C, Ross RP (2015) Bioengineering lantibiotics for therapeutic success. Front Microbiol 6:1363. https://doi.org/10.3389/fmicb .2015 .01363

Flühe L, Knappe TA, Gattner MJ et al (2012) The radical SAM enzyme AlbA catalyzes thioether bond formation in subtilosin A. Nat Chem Biol 8:350-357. https://doi.org/10.1038/nchembio.798

Fuchs SW, Jaskolla TW, Bochmann S et al (2011) Entianin, a novel subtilin-like lantibiotic from Bacillus subtilis subsp. spizizenii DSM 15029 T with high antimicrobial activity. Appl Environ Microbiol 77:1698-1707. https://doi. org/10.1128/AEM.01962-10

Gabrielsen C, Brede DA, Nes IF, Diep DB (2014) Circular bacteriocins: biosynthesis and mode of action. Appl Environ Microbiol 80:6854-6862. https:// doi.org/10.1128/AEM.02284-14

Garg N, Tang W, Goto Y et al (2012) Lantibiotics from Geobacillus thermodenitrificans. Proc Natl Acad Sci USA 109:5241-5246. https://doi.org/10.1073/ pnas.1116815109

Garg N, Oman TJ, Andrew Wang T-S et al (2014) Mode of action and structureactivity relationship studies of geobacillin I. J Antibiot 67:133-136. https ://doi.org/10.1038/ja.2013.112

Ge J, Kang J, Ping W (2019) Effect of acetic acid on bacteriocin production by gram-positive bacteria. J Microbiol Biotechnol 29:1341-1348

Geiger C, Spieß T, Korn SM et al (2017) Specificity of subtilin-mediated activation of histidine kinase SpaK. Appl Environ Microbiol 83:e00781-17. https://doi.org/10.1128/AEM.00781-17

Ghanbari M, Rezaei M, Soltani M et al (2009) Production of bacteriocin by a novel Bacillus sp. strain RF 140, an intestinal bacterium of Caspian Frisian Roach (Rutilus frisii kutum). Iran J Vet Res 10:267-272

Goto Y, Li B, Claesen J et al (2010) Discovery of unique lanthionine synthetases reveals new mechanistic and evolutionary insights. PLoS Biol 8:e1000339. https://doi.org/10.1371/journal.pbio.1000339

Halimi B, Dortu C, Arguelles-Arias A et al (2010) Antilisterial activity on poultry meat of amylolysin, a bacteriocin from Bacillus amyloliquefaciens GA1. Probiotics Antimicrob Proteins 2:120-125. https://doi.org/10.1007/ s12602-010-9040-9

Hammami I, Triki MA, Rebai A (2011) Purification and characterization of the novel bacteriocin $\mathrm{Bac} \mathrm{IH7}$ with antifungal and antibacterial properties. J Plant Pathol 93:443-454. https://doi.org/10.2307/41999016

Hanafy AM, Al-Mutairi AA, Al-Reedy RM et al (2016) Phylogenetic affiliations of Bacillus amyloliquefaciens isolates produced by a bacteriocin-like substance in goat milk. Integr Med Res 10:631-641. https://doi. org/10.1016/j.jtusci.2016.02.007

Hatcher N, Moon S, Wolf JR (2015) Partial characterization of a novel bacteriocin from Bacillus cereus GS1, a soil isolate. J Ky Acad Sci 75:37-46. https ://doi.org/10.3101/kyac-75-01-37-46.1

He L, Chen W, Liu Y (2006) Production and partial characterization of bacteriocin-like peptides by Bacillus licheniformis ZJU12. Microbiol Res 161:321-326. https://doi.org/10.1016/j.micres.2005.12.002

He Z, Kisla D, Zhang L et al (2007) Isolation and identification of a Paenibacillus polymyxa strain that coproduces a novel lantibiotic and polymyxin. 
Appl Environ Microbiol 73:168-178. https://doi.org/10.1128/AEM.02023 $-06$

Herzner AM, Dischinger J, Szekat C et al (2011) Expression of the lantibiotic mersacidin in Bacillus amyloliquefaciens FZB42. PLoS ONE 6:e22389. https://doi.org/10.1371/journal.pone.0022389

Huang E, Yousef AE (2015) Biosynthesis of paenibacillin, a lantibiotic with $\mathrm{N}$-terminal acetylation, by Paenibacillus polymyxa. Microbiol Res 181:15-21. https://doi.org/10.1016/j.micres.2015.08.001

Huang T, Zhang X, Pan J et al (2016) Purification and characterization of a novel cold shock protein-like bacteriocin synthesized by Bacillus thuringiensis. Sci Rep 6:35560. https://doi.org/10.1038/srep35560

Hyronimus B, Le Marrec C, Urdaci MC (1998) Coagulin, a bacteriocin-like inhibitory substance produced. J Appl Microbiol 85:42-50

Islam MR, Nagao J-I, Zendo T, Sonomoto K (2012) Antimicrobial mechanism of lantibiotics. Biochem Soc Trans 40:1528-1533. https://doi.org/10.1042/ BST20120190

Jarrett JT (2014) The biosynthesis of thiol-and thioether-containing cofactors and secondary metabolites catalyzed by radical s-adenosylmethionine enzymes. J Biol Chem 290:3972-3979. https://doi.org/10.1074/jbc. R114.599308

Joseph B, Dhas B, Hena V et al (2013) Bacteriocin from Bacillus subtilis as a novel drug against diabetic foot ulcer bacterial pathogens. Asian Pac J Trop Biomed 3:942-946. https://doi.org/10.1016/S2221-1691(13)60183 $-5$

Kaboré D, Sandris Nielsen D, Sawadogo-Lingani H et al (2013) Inhibition of Bacillus cereus growth by bacteriocin producing Bacillus subtilis isolated from fermented baobab seeds (maari) is substrate dependent. Int J Food Microbiol 162:114-119. https://doi.org/10.1016/j.ijfoodmicr 0.2012 .12 .027

Kaewklom S, Lumlert S, Kraikul W, Aunpad R (2013) Control of Listeria monocytogenes on sliced bologna sausage using a novel bacteriocin, amysin, produced by Bacillus amyloliquefaciens isolated from Thai shrimp paste (Kapi). Food Control 32:552-557. https://doi.org/10.1016/j.foodc ont.2013.01.012

Kawulka KE, Sprules T, Diaper CM et al (2004) Structure of subtilosin A, a cyclic antimicrobial peptide from Bacillus subtilis with unusual sulfur to a-carbon cross-links: formation and reduction of a-thio-a-amino acid derivatives. Biochemistry 43:3385-3395. https://doi.org/10.1021/bi035 9527

Kayalvizhi N, Gunasekaran P (2010) Purification and characterization of a novel broad-spectrum bacteriocin from Bacillus licheniformis MKU3. Biotechnol Bioprocess Eng 15:365-370. https://doi.org/10.1007/s1225 7-009-0164-2

Khatri I, Sharma S, Ramya TN, Subramanian S (2016) Complete genomes of Bacillus coagulans S-lac and Bacillus subtilis TO-A JPC, two phylogenetically distinct probiotics. PLoS One 11(6):e0156745. https://doi. org/10.1371/journal.pone.0156745

Khochamit N, Siripornadulsil S, Sukon P, Siripornadulsil W (2015) Antibacterial activity and genotypic-phenotypic characteristics of bacteriocin-producing Bacillus subtilis KKU213: potential as a probiotic strain. Microbiol Res 170:36-50. https://doi.org/10.1016/j.micres.2014.09.004

Kim Y-O, Park I-S, Kim D-J et al (2014) Identification and characterization of a bacteriocin produced by an isolated Bacillus Sp. SW1-1 that exhibits antibacterial activity against fish pathogens. J Korean Soc Appl Biol Chem 57:605-612. https://doi.org/10.1007/s13765-014-4174-1

Kindoli S, Lee HA, Heo K, Kim JH (2012) Properties of a bacteriocin from Bacillus subtilis $\mathrm{H} 27$ isolated from Cheonggukjang. Food Sci Biotechnol 21:1745-1751. https://doi.org/10.1007/s10068-012-0232-9

Kobayashi T, Agustini TW, Ibrahim R et al (2016) Production of bacteriocin by Virgibacillus salexigens isolated from "terasi": a traditionally fermented shrimp paste in Indonesia. World J Microbiol Biotechnol 32:47. https:// doi.org/10.1007/s11274-015-1991-2

Kurata A, Yamaguchi T, Kira M, Kishimoto N (2019) Characterization and heterologous expression of an antimicrobial peptide from Bacillus amyloliquefaciens CMW1. Biotechnol Biotechnol Equip 33:886-893. https://doi.org/10.1080/13102818.2019.1627246

Lawton EM, Cotter PD, Hill C, Ross RP (2007) Identification of a novel twopeptide lantibiotic, Haloduracin, produced by the alkaliphile Bacillus halodurans C-125. FEMS Microbiol Lett 267:64-71. https://doi.org/10.11 $11 / j .1574-6968.2006 .00539 . x$
Lee HA, Hwan Kim J (2012) Properties of bac W42, a bacteriocin produced by Bacillus subtilis W42 isolated from Cheonggukjang. J Microbiol Biotechnol 22:1092-1100. https://doi.org/10.4014/jmb.1110.10002

Lee K-H, Jun K-D, Kim W-S, Paik H-D (2001) Partial characterization of polyfermenticin SCD, a newly identified bacteriocin of Bacillus polyfermenticus. Lett Appl Microbiol 32:146-151. https://doi.org/10.1046/j.1472765x.2001.00876.x

Leite JA, Tulini FL, dos Reis-Teixeira FB et al (2016) Bacteriocin-like inhibitory substances (BLIS) produced by Bacillus cereus: preliminary characterization and application of partially purified extract containing BLIS for inhibiting Listeria monocytogenes in pineapple pulp. LWT Food Sci Technol 72:261-266. https://doi.org/10.1016/j.lwt.2016.04.058

Lim KB, Balolong MP, Hoon Kim S et al (2016) Isolation and characterization of a broad spectrum bacteriocin from Bacillus amyloliquefaciens RX7. Biomed Res Int 2016:8521476. https://doi.org/10.1155/2016/8521476

Liu Z, Budiharjo A, Wang P et al (2013) The highly modified microcin peptide plantazolicin is associated with nematicidal activity of Bacillus amyloliquefaciens FZB42. Appl Microbiol Biotechnol 97:10081-10090. https://doi.org/10.1007/s00253-013-5247-5

Liu X, Lee JY, Jeong S-J et al (2015) Properties of a bacteriocin produced by Bacillus subtilis EMD4 isolated from Ganjang (Soy Sauce). J Microbiol Biotechnol 25:1493-1501. https://doi.org/10.4014/jmb.1502.02037

Lohans CT, Vederas JC (2014) Structural characterization of thioether-bridged bacteriocins. J Antibiot 67:23-30. https://doi.org/10.1038/ja.2013.81

Luca M, Mario V, Gino N, De Felice M (2002) Purification and partial characterization of bacillocin 490, a novel bacteriocin produced by a thermophilic strain of Bacillus licheniformis. Microb Cell Fact 91:1-5. https://doi. org/10.1046/j.1365-2672.2001.01429.x

Maria T, llias F, Gerda K, Antigoni M (2012) Partial purification and characterization of a bacteriocin produced by Bacillus subtilis NCIMB 3610 that exhibits antimicrobial activity against fish pathogens. J Biol Res 18:310-319

Martínez-Cardeñas JA, De La Fuente-Salcido NM, Salcedo-Hernández R et al (2012) Effects of physical culture parameters on bacteriocin production by Mexican strains of Bacillus thuringiensis after cellular induction. J Ind Microbiol Biotechnol 39:183-189. https://doi.org/10.1007/s1029 5-011-1014-8

Martin-Visscher LA, van Belkum MJ, Vederas JC (2011) Class Ilc or circular bacteriocins. Prokaryotic antimicrobial peptides. Springer, New York, pp 213-236

Mathur H, Fallico V, O'Connor PM et al (2017) Insights into the mode of action of the sactibiotic thuricin CD. Front Microbiol 8:696. https://doi. org/10.3389/fmicb.2017.00696

McAuliffe O, Ross RP, Hill C (2001) Lantibiotics: structure, biosynthesis and mode of action. FEMS Microbiol Rev 25:285-308. https://doi. org/10.1111/j.1574-6976.2001.tb00579.x

Mickymaray S, Alturaiki W, Al-Aboody MS et al (2018) Anti-bacterial efficacy of bacteriocin produced by marine Bacillus subtilis against clinically important extended spectrum beta-lactamase strains and methicillinresistant Staphylococcus aureus. Int J Med Res Health Sci 7:75-83

Motta AS, Brandelli A (2008) Evaluation of environmental conditions for production of bacteriocin-like substance by Bacillus sp. strain P34. World J Microbiol Biotechnol 24:641-646. https://doi.org/10.1007/s1127 4-007-9520-6

Murphy K, O'Sullivan O, Rea MC et al (2011) Genome mining for radical SAM protein determinants reveals multiple sactibiotic-like gene clusters. PLoS ONE 6:e20852. https://doi.org/10.1371/journal.pone.0020852

Nagao J, Nishie M, Sonomoto K (2011) Methodologies and strategies for the bioengineering of lantibiotics. Curr Pharm Biotechnol 12:1221-1230. https://doi.org/10.2174/138920111796117355

Ovchinnikov KV, Chi H, Mehmeti I et al (2016) Novel group of leaderless multipeptide bacteriocins from gram-positive bacteria. Appl Environ Microbiol 82:5216-5224. https://doi.org/10.1128/AEM.01094-16

Pacheco-Cano RD, De La Fuente-Salcido NM, Salcedo-Hernández R et al (2014) Characterization, $\mathrm{N}$-terminal sequencing and classification of tolworthcin 524: a bacteriocin produced by Bacillus thuringiensis subsp. to/worthi. Microbiol Res 169:948-953. https://doi.org/10.1016/j.micre s.2014.04.005 
Patrick F, Valérie L, Jean-Sébastien G et al (2008) Temperature dependence of mycosubtilin homologue production in Bacillus subtilis ATCC6633. Res Microbiol 159:449-457. https://doi.org/10.1016/J.RESMIC.2008.05.004

Pattnaik P, Kaushik JK, Grover S, Batish VK (2001) Purification and characterization of a bacteriocin-like compound (Lichenin) produced anaerobically by Bacillus licheniformis isolated from water buffalo. J Appl Microbiol 91:636-645. https://doi.org/10.1046/j.1365-2672.2001.01429.x

Pattnaik P, Grover S, Batish VK (2005) Effect of environmental factors on production of lichenin, a chromosomally encoded bacteriocin-like compound produced by Bacillus licheniformis 26L-10/3RA. Microbiol Res 160:213-218. https://doi.org/10.1016/.jmicres.2005.01.006

Perumal V, Yao Z, Kim JA et al (2019) Purification and characterization of a bacteriocin, bacBS2, produced by bacillus velezensis BS2 isolated from meongge jeotgal. J Microbiol Biotechnol 29:1033-1042. https://doi. org/10.4014/jmb.1903.03065

Phelan RW, Barret M, Cotter PD et al (2013) Subtilomycin: a new lantibiotic from Bacillus subtilis strain MMA7 isolated from the marine sponge Haliclona simulans. Mar Drugs 11:1878-1898. https://doi.org/10.3390/ md1 1061878

Pohilenko VD, Perelygin VV, Sadikova GT et al (2014) Strain Bacillus lentus-producer of bacteriocin-like substance of antimicrobial action and method of obtaining bacteriocin-like substance, Russian patents, RU2530552C1

Pokusaeva K, Kuisiene N, Jasinskyte D et al (2009) Novel bacteriocins produced by Geobacillus stearothermophilus. Cent Eur J Biol Res 4:196-203. https ://doi.org/10.2478/s11535-009-0009-1

Qin Y, Wang Y, He Y et al (2019) Characterization of subtilin L-Q11, a novel class I bacteriocin synthesized by Bacillus subtilis L-Q11 isolated from orchard soil. Front Microbiol. https://doi.org/10.3389/fmicb.2019.00484

Ratchaneewan A, Pipatsatitpong D (2014) Isolation and characterization of a bacteriocin with anti-MRSA activity from Bacillus sp. strain WASM9-25M. Thai J Pharmacol 36:19-28

Rea MC, Sit CS, Clayton E et al (2010) Thuricin CD, a posttranslationally modified bacteriocin with a narrow spectrum of activity against Clostridium difficile. Proc Natl Acad Sci USA 107:9352-9357. https://doi.org/10.1073/ pnas.0913554107

Repka LM, Chekan JR, Nair SK, van der Donk WA (2017) Mechanistic understanding of lanthipeptide biosynthetic enzymes. Chem Rev 117:54575520. https://doi.org/10.1021/acs.chemrev.6b00591

Salazar-Marroquín EL, Galán-Wong LJ, Moreno-Medina VR et al (2016) Bacteriocins synthesized by Bacillus thuringiensis: generalities and potential applications. Rev Med Microbiol 27:95-101. https://doi.org/10.1097/ MRM.0000000000000076

Saleem F, Ahmad S, Yaqoob Z et al (2009) Comparative study of two bacteriocins produced by representative indigenous soil bacteria. Pak J Pharm Sci 22:252-258

Sandiford S (2017) Perspectives on lantibiotic discovery-where have we failed and what improvements are required? Expert Opin Drug Discov 10:315-320. https://doi.org/10.1517/17460441.2015.1016496

Schmitz S, Hoffmann A, Szekat C et al (2006) The lantibiotic mersacidin is peptide. Appl Environ Microbiol 72:7270-7277. https://doi.org/10.1128/ AEM.00723-06

Scholz R, Vater J, Budiharjo A et al (2014) Amylocyclicin, a novel circular bacteriocin produced by Bacillus amyloliquefaciens FZB42. J Bacteriol 196:1842-1852. https://doi.org/10.1128/JB.01474-14

Senbagam D, Gurusamy R, Senthilkumar B (2013) Physical chemical and biological characterization of a new bacteriocin produced by Bacillus cereus NS02. Asian Pac JTrop Med 6:934-941. https://doi.org/10.1016/ S1995-7645(13)60167-4

Sharma N, Kapoor G, Gautam N, Neopaney B (2009) Characterization of a partially purified bacteriocin of Bacillus sp. MTCC 43 isolated from Rhizosphere of radish (Raphanus sativus) \& its application as a potential food biopreservative. J Sci Ind Res 68:881-886

Sharma N, Kapoor R, Gautam N, Kumari R (2011) Purification and characterization of bacteriocin produced by Bacillus subtilis R75 isolated from fermented chunks of Mung Bean (Phaseolus radiatus). Food Technol Biotechnol 49:169-176

Shayesteh F, Ahmad A, Usup G (2014) Bacteriocin production by a marine strain of Bacillus sp. Sh 10: isolation, screening and optimization of culture condition. Biotechnology 13:273-281. https://doi.org/10.3923/ biotech.2014.273.281
Shi Y, Bueno A, van der DonkWA (2012) Heterologous production of the lantibiotic Ala(0)actagardine in Escherichia coli. Chem Commun 48:10966-10968. https://doi.org/10.1039/c2cc36336d

Singh M, Sareen D (2014) Novel LanT associated lantibiotic clusters identified by genome database mining. PLoS ONE 9:e91352. https://doi. org/10.1371/journal.pone.0091352

Singh PK, Chittpurna A, Le Ashish C et al (2012) Identification, purification and characterization of laterosporulin, a novel bacteriocin produced by Brevibacillus sp. strain GI-9. PLoS ONE 7:e31498. https://doi.org/10.1371/ journal.pone.0031498

Somsap O, Bangrak P, Bhoopong P, Lertcanawanichakul M (2016) Antibacterial activity and purification of bacteriocin produced by Brevibacillus laterosporus SA14 On-anong. Walailak J Sci Technol 13:55-65

Spieß T, Korn SM, Kötter P, Entian K-D (2015) Autoinduction specificities of the lantibiotics subtilin and nisin. Appl Environ Microbiol 81:7914-7923. https://doi.org/10.1128/AEM.02392-15

Svetoch EA, Stern NJ, Eruslanov BV et al (2005) Isolation of Bacillus circulans and Paenibacillus polymyxa strains inhibitory to Campylobacter jejuni and characterization of associated bacteriocins. J Food Prot 68:11-17

Teng Y, Zhao W, Qian C et al (2012) Gene cluster analysis for the biosynthesis of elgicins, novel lantibiotics produced by Paenibacillus elgii B69. BMC Microbiol 12:45. https://doi.org/10.1186/1471-2180-12-45

Tseng CC, Murni L, Han TW et al (2019) Molecular characterization and heterologous production of the bacteriocin peocin, a DNA starvation/stationary phase protection protein, from Paenibacillus ehimensis NPUST1. Molecules 24:2516. https://doi.org/10.3390/molecules24132516

van der Donk WA, Nair SK (2014) Structure and mechanism of lanthipeptide biosynthetic enzymes. Curr Opin Struct Biol 29:58-66. https://doi. org/10.1016/j.sbi.2014.09.006

Van Staden ADP, Heunis T, Smith C et al (2016) Efficacy of lantibiotic treatment of Staphylococcus aureus-induced skin infections, monitored by in vivo bioluminescent imaging. Antimicrob Agents Chemother 60:3948-3955. https://doi.org/10.1128/AAC.02938-15

Wang G, Manns DC, Churey JJ, Worobo RW (2014a) Development of a homologous expression system for and systematic site-directed mutagenesis analysis of thurincin $\mathrm{H}$, a bacteriocin produced by Bacillus thuringiensis SF361. Appl Environ Microbiol 80:3576-3584. https://doi.org/10.1128/ AEM.00433-14

Wang J, Zhang L, Teng K et al (2014b) Cerecidins, novel lantibiotics from Bacillus cereus with potent antimicrobial activity. Appl Environ Microbiol 80:2633-2643. https://doi.org/10.1128/AEM.03751-13

Wieckowski BM, Hegemann JD, Mielcarek A et al (2015) The PqqD homologous domain of the radical SAM enzyme ThnB is required for thioether bond formation during thurincin H maturation. FEBS Lett 589:18021806. https://doi.org/10.1016/j.febslet.2015.05.032

Xie J, Zhang R, Shang C, Guo Y (2009) Isolation and characterization of a bacteriocin produced by an isolated Bacillus subtilis LFB1 12 that exhibits antimicrobial activity against domestic animal pathogens. Afr J Biotechnol 8:5611-5619

Xin B, Zheng J, Xu Z et al (2015) Three novel lantibiotics, ticins A1, A3, and A4, have extremely stable properties and are promising food biopreservatives. Appl Environ Microbiol 81:6964-6972. https://doi.org/10.1128/ AEM.01851-15

Xin B, Zheng J, Liu H et al (2016) Thusin, a novel two-component lantibiotic with potent antimicrobial activity against several Gram-positive pathogens. Front Microbiol 7:1-12. https://doi.org/10.3389/fmicb.2016.01115

Yang Y, Kim Y, Hong J, Lee C (2002) Characterization of subtilein, a bacteriocin from Bacillus subtilis CAU131 (KCCM 10257). J Microbiol Biotechnol 12:228-234

Yu Y, Zhang Q, van der DonkWA (2013) Insights into the evolution of lanthipeptide biosynthesis. Protein Sci 22:1478-1489. https://doi.org/10.1002/ pro.2358

Yusra Y, Azima F, Novelina N, Periadnadi P (2014) Characterization of antimicrobial bacteriocin produced by Bacillus cereus SS28 isolates from Budu, a traditionally fermented fish product of West Sumatera. Microbiol Indones 8:24-32. https://doi.org/10.5454/mi.8.1.4

\section{Publisher's Note}

Springer Nature remains neutral with regard to jurisdictional claims in published maps and institutional affiliations. 